Article

\title{
Evaluation of Sources and Ecological Risk of PAHs in Different Layers of Soil and Groundwater
}

\author{
Predrag Ilić ${ }^{1}$, Dragana Nešković Markić ${ }^{2, *}$ and Ljiljana Stojanović Bjelić ${ }^{1}$ \\ 1 PSRI Institute for Protection and Ecology of the Republic of Srpska, Banja Luka; pedja_1979@yahoo.co.uk \\ 2 Pan-European University “APEIRON”, Banja Luka; dragana.d.neskovicmarkic@apeiron-edu.eu (D.NM.); \\ ljiljana.v.stojanovicbjelic@apeiron-edu.eu (Lj. SB.) \\ * Correspondence: pedja_1979@yahoo.co.uk; Tel.: +387-51-218-318
}

\begin{abstract}
Research subjects of this study are four representative locations in the industrial complex, in the city of Banja Luka, Republic of Srpska, Bosnia and Herzegovina. 16 polycyclic aromatic hydrocarbons (PAHs) ( $(16 \mathrm{PAHs})$, humus and $\mathrm{pH}$ were determined. The main objective of the paper is to determine the concentration levels, to assess the probable sources of PAHs contamination in soil and groundwater and to determine the ecological risk. The $\Sigma 16 \mathrm{PAH}$ in soil (at depths of $30 \mathrm{~cm}, 100$ $\mathrm{cm}, 200 \mathrm{~cm}, 300 \mathrm{~cm}$ and $400 \mathrm{~cm}$ ) ranged from 0.99 to $2.24 \mathrm{mg} / \mathrm{kg}$, from 0.34 to 0.46 , from 0.24 to 0.32 , from 0.13 to 0.27 and from 0.13 to 0.47 , with mean values of $1.70 \mathrm{mg} / \mathrm{kg}, 0.40 \mathrm{mg} / \mathrm{kg}, 0.28 \mathrm{mg} / \mathrm{kg}, 0.20$ $\mathrm{mg} / \mathrm{kg}$ and $0.26 \mathrm{mg} / \mathrm{kg}$, respectively. The $\sum 16 \mathrm{PAHs}$ in ground water ranged from 0.23 to $4.50 \mathrm{mg} / \mathrm{m}^{3}$, with a mean value of $1.42 \mathrm{mg} / \mathrm{m}^{3}$. Surface soil and groundwater are heavily contaminated. All values of $\sum$ PAHs in soil layers were lower in the depths of the soil. Factor analysis indicates three sources of contamination, i.e. principal component (PC) PC1 (pyrogenic), PC2 (petrogenic) and PC3 (biomass), with $52.39 \%, 26.14 \%$ and $8.46 \%$ of the total variance, respectively. $\Sigma \mathrm{PAH}$ and $\mathrm{PAHs}$ indicate high ecological risk for most PAHs, which decreases with soil depth.
\end{abstract}

Keywords: soil; groundwaters; polycyclic aromatic hydrocarbons (PAHs); industrial complex; ecological risk; contamination

\section{Introduction}

Polycyclic aromatic hydrocarbons (PAHs) are a large group of organic compounds containing two or more benzene rings in their structure. PAHs are formed through natural and anthropogenic sources. PAHs are produced from anthropogenic activities, i.e. industrial emissions, incomplete combustion of petroleum, coal and other fossil fuels and other industrial and domestic activities [16]. Natural sources of PAHs formation are volcanoes, bacterial and algal synthesis, forest fires, petroleum seeps, erosion of sedimentary rocks containing petroleum hydrocarbons and decomposition of vegetative litterfall [7]. These compounds are widely present in the air, water, aquatic system, soils and sediments [8]. There are more than 100 different types of PAHs [9]. Although there are many PAHs, most analyses and data report focus on typically between 14 and 20 individual PAHs.

PAHs can be divided into two categories: low molecular weight compounds consisting of fewer than four aromatic rings (2, 3 and 4 rings) and high molecular weight compounds consisting of five and six aromatic rings. Pure PAHs are usually colored, crystalline solids at ambient temperature [10], and they have high melting and boiling points, low vapor pressure and very low aqueous solubility. These compounds are very soluble in organic solvents and are lipophilic [11,12].

PAHs in groundwaters are non-degradable and remain present for long periods of time [13]. In soil and aquifer system these components are sorbed into organic and clay fraction restricting their bioavailability $[14,15]$. They are present in the atmosphere both in the gaseous state and associated 
with particles and can potentially travel long distances reaching remote areas [16]. The reason for concern about PAHs is that they are dangerous for human health, because some of them have toxic, mutagenic and/or carcinogenic effect [17]. The main route of PAHs intake in humans is inhalation, but dermal contact and ingestion routes have also to be taken into account [18]. A large number of health studies suggests a link between lung cancer and exposure to PAHs [19], as well as infertility and damage in infants and adults exposed to PAHs in the work environment or from ambient air [18]. PAHs have a negative impact on the aquatic living world and birds, causing tumor formation, reproductive problems and immunity problems. Due to the persistence and bioaccumulative effect, the concentrations of PAHs in fish and shellfish have far greater values than the environment in which they are found. On the other hand, the plants absorb PAHs from the soil through the root system and they go to other parts of the plant (trunk, leaves and fruits) [7].

A large number of studies of PAHs in soil was performed in the world: Germany [20], France [21], Austria [22], China [23], USA [24], South Africa [25], Antarctic [26]. Brindha \& Elango [27] have identified in their study the presence of PAHs in groundwater in Chennai, Tamil Nandu, India. Li et al. [13] have researched the behavior of PAHs in surface and groundwater of the Yellow River, China, while Sun et al. [28] in their study researched vertical migration of PAHs from surface soils to groundwater.

Systematic studies on PAHs contamination in Bosnia and Herzegovina in surface soil have been rare, while the research of PAHs at different depths was not conducted.In Bosnia and Herzegovina analyses of PAHs in soil, air and sediment have been performed. Analyses were performed in playgrounds soil in the city of Sarajevo [29], while an examination study of POPs and PAHs in ambient air in the Central and Eastern Europe was also conducted in Bosnia and Herzegovina [30], as well as analyses of POPs and PAHs in sediment in the Neretva River [31].

A study of air PAHs in urban and rural areas was conducted in the City of Banja Luka in 2008 $[32,33]$. The results of this study show that the value of PAHs in the urban area was much higher than in rural area.

The importance of the research in the paper is that soil samples have been taken in different layers, up to $4 \mathrm{~m}$ in depth, while in other studies, the greatest depths were up to $20 \mathrm{~cm} \mathrm{[34],} 40 \mathrm{~cm} \mathrm{[6],}$ $50 \mathrm{~cm} \mathrm{[3]} \mathrm{and} 100 \mathrm{~cm}$ [28].

This study examined the concentrations of 16 PAHs in soil and groundwater in an industrial complex (locality Incel) (former Cellulose Factory) in the city of Banja Luka, Republic of Srpska, Bosnia and Herzegovina. The main objective of the paper is to determine the concentration levels, evaluate contamination of soil, determine the ecological risk of PAHs in soil and groundwater and assess the probable sources of PAHs contamination in locations with high pollution in the city of Banja Luka.

\section{Materials and Methods}

\subsection{Location Sampling}

The subject of the research in the study was to measure the PAHs concentration in the high pollution soil and groundwater in the industrial complex. Banja Luka is a city in the Republic of Srpska, Bosnia and Herzegovina. Banja Luka is the second biggest city in Bosnia and Herzegovina with the population of 185,000 . The city is situated in a basin of $164 \mathrm{~m}$ above sea level. The average annual temperature reaches $10.7^{\circ} \mathrm{C}$. The lowest temperatures range from $-5.6^{\circ} \mathrm{C}$ to $-27^{\circ} \mathrm{C}$ and the highest from $31.4^{\circ} \mathrm{C}$ to $41.4^{\circ} \mathrm{C}$.

The industrial complex is a former company based in Banja Luka, originally manufacturing cellulose, viscose and paper products. Established in 1954, it was a major industrial conglomerate in the field during the Socialist Era, employing up to 6,500 workers. Following a period of decline in the 1980s and the War in Bosnia and Herzegovina in 1990s, the factory was destroyed, and was subsequently split into several smaller enterprises. This industrial complex is at a distance of $3 \mathrm{~km}$ from the city centre. 
The industrial complex location was selected for the research, as earlier studies have pointed to high contamination with heavy metals $(\mathrm{Cd}, \mathrm{Pb}, \mathrm{Ni}, \mathrm{Cu}$, and $\mathrm{Hg}$ ) and organic pollutants (Polycyclic Aromatic Hydrocarbons (PCB) and Total Petroleum Hydrocarbons (TPH)) [35]. Soil and groundwater analyses were carried out at locations. Wells (piezometers) were made at locations for future groundwater research (S1, S2, S3, and S4) (Figure 1).
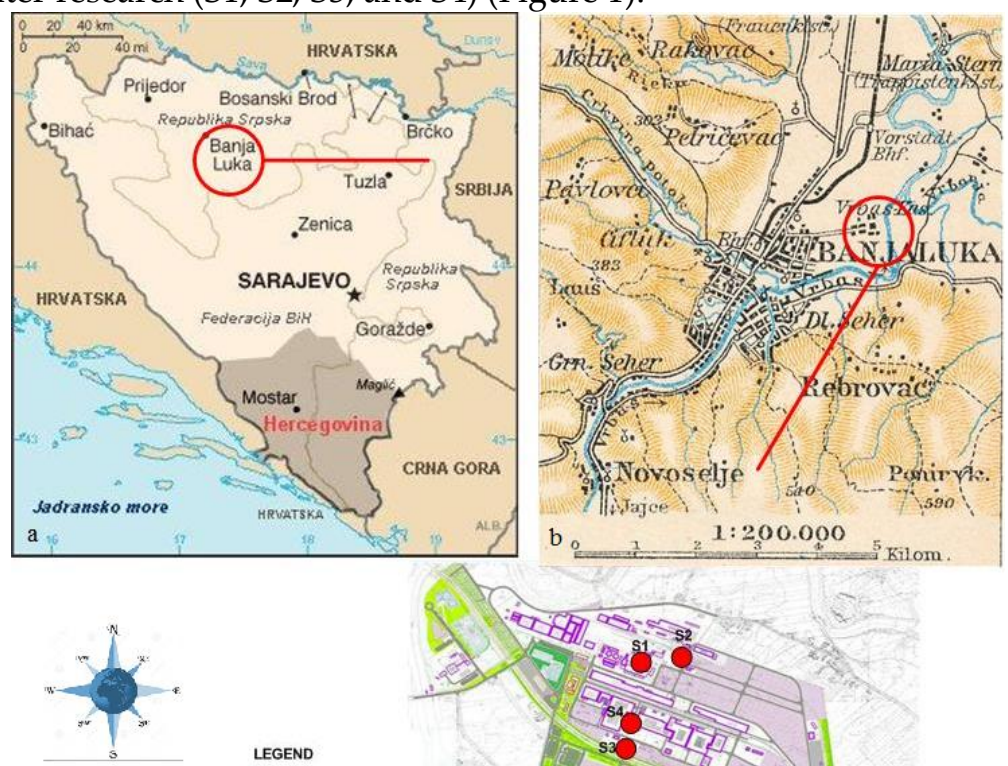

\section{LEGEND}
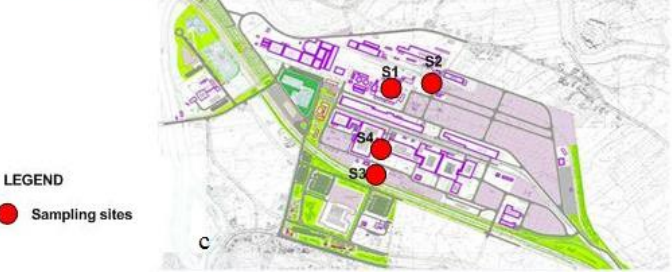

Figure 1. Location of sampling (a) Country Bosnia and Herzegovina, (b) City of Banja Luka, (c) Industrial complex.

\subsection{Analysis and the quality assurance and control (QA/QC)}

A total of 16 soil and 4 groundwater samples were collected from four locations in the industrial complex, from different layers of soil (at a depth of $30 \mathrm{~cm}, 100 \mathrm{~cm}, 200 \mathrm{~cm}, 300 \mathrm{~cm}$, and $400 \mathrm{~cm}$ ) and groundwater from each location. Geological characteristics of the soil by layers are given in Table 1.

Table 1. Soil characteristics by layers in which samples were taken

\begin{tabular}{cc}
\hline $\begin{array}{c}\text { Layer } \\
\text { thickness } \\
(\mathbf{c m})\end{array}$ & Lithological description \\
\hline 30 & $\begin{array}{c}\text { Gray and gray-yellow clays with dust and pebbles, } \\
\text { partially humified, with plant detritus in one location } \\
\text { Gray-yellow clays with dust and pebbles, partly with } \\
\text { plant detritus with an intercalation of greasy black clays } \\
\text { in one location and gravel grains in other location } \\
\text { Gray-yellow clay, gravelly and dusty, and in one location } \\
\text { black, plastic clay, partly dusty }\end{array}$ \\
300 & $\begin{array}{r}\text { Clayey gravel with pebbles, clay gravel with pebbles, } \\
\text { gray-yellow dusty clays with pebbles, and gray and gray- } \\
\text { yellow clayey sand with pebbles }\end{array}$ \\
& Clay, clayey gravel and clayey gravel with large pebbles \\
\hline
\end{tabular}

Soil and groundwater samples were collected during August 2019. Chemical analyses were conducted for 16 types of PAHs by using Gas chromatography. The detector used for PAH analysis is a mass detector coupled with the gas chromatograph (GC-MS). Physical analyses in soil were conducted: acidity $(\mathrm{pH})$ measured in deionized water, and organic matter (humus) content applying 
the Tyurin's method [36]. Components of PAHs that were analysed were: naphthalene (Nap, 2-ring), acenaphthylene (Acy, 3-ring), acenaphthene (Ace, 3-ring), fluorine (Flo, 3-ring), phenanthrene (Phe, 3-ring) and anthracene (Ant, 3-ring) and high molecular weight PAHs (HMWPAHs) with 4-6 aromatic rings such as fluoranthene (Fluo, 4-ring) pyrene (Pyr, 4-ring) benzo[a]anthracene (BaA, 4ring), chrysene ( $\mathrm{Chr}$, 4-ring), benzo[b]fluoranthene (BbF, 5-ring), benzo[k]fluoranthene (BkF, 5-ring), benzo[a]-pyrene (BaP, 5-ring), indeno[1,2,3-cd]pyrene (IcdP, 6-ring), dibenzo[a,h]anthracene (DahA, 5-ring) and benzo[g,h,i]perylene (BghiP, 6-ring). The process of extraction and obtained PAHs concentrations were further processed based on the principles described in standard methods with disintegration techniques and analysed in accordance with national legislation $[37,38]$ and accredited standard method EPA 8270D/3550C:2007 for soil and EPA 8270D/EPA 3510 forwater [39]. Accredited quantification limit for PAH in soil is $0,02 \mathrm{mg} / \mathrm{kg}$ and for water $0,03 \mathrm{ug} / \mathrm{l}$.

Quality assurance and control $(\mathrm{QA} / \mathrm{QC})$ was attained following strict quality assurance and control measures. The identification of the source of uncertainty was made on the basis of the uncertainty arising from the gas chromatograph (sample capture), the preparation of standard solutions for the calibration of the instrument, the measurement of the sample, the accuracy of sample measurement in a normal vessel, the measurement of the volume of the concentrated extract and the uncertainty arising from the variation of temperature.

In order to obtain experimental results for soil and groundwater analysis, the method of spiking the sample matrix - blind trials with the known amount of analytes tested and analysis of the control samples thus obtained was used. The verification procedure covers the following parameters: instrument calibration, repeatability, return, limit of detection (LOD) and limit of quantification (LOQ). The validation of the analytical method was also carried out through a recovery study. The spiked samples were analyzed in the same way as actual samples.

Instrument calibration was done using certified analytical standards. A series of 5 standard solutions were prepared. Linearity was tested in the concentration range from $0,03-0,66 \mathrm{mg} / \mathrm{kg}$ (in the sample), i.e. from $100-2000 \mu \mathrm{g} / \mathrm{l}$ for soil and $30-2000 \mu \mathrm{g} / \mathrm{l}$ for water.

The LOD and LOQ values for the determination of hydrocarbons were determined. An evaluation of the baseline standard deviation, as well as the ratio between peak analyte height and the baseline standard deviation was used to determine these limits in the manner prescribed in the instruction Agilent Technologies: Validation of Analytical Methods.

$$
\mathrm{LOD}=3 \cdot \mathrm{S} / \mathrm{a} \quad \mathrm{LOQ}=10 \cdot \mathrm{S} / \mathrm{a}
$$

where: $\mathrm{S}$ - standard model error and a - slope coefficient.

The limit of detection (LOD) and limit of quantification (LOQ) for the investigated PAHs in soil and water are presented in Table 2.

Table 2. Limit of detection (LOD) and limit of quantification (LOQ) for six PAHs congeners

\begin{tabular}{ccccc}
\hline \multirow{2}{*}{ PAHs } & \multicolumn{2}{c}{ Soil } & \multicolumn{2}{c}{ Water } \\
\cline { 2 - 5 } & LOD (mg/kg) & LOQ (mg/kg) & LOD (mg/l) & LOQ (mg/l) \\
\hline Nap & 0,0054 & 0,018 & 0.0045 & 0.015 \\
Chr & 0,0048 & 0,016 & 0,0075 & 0,025 \\
Pyr & 0,0048 & 0,016 & 0,0078 & 0,026 \\
BaP & 0,0054 & 0,018 & 0,0069 & 0,018 \\
IcdP & 0,0057 & 0,019 & 0,0075 & 0,025 \\
Phe & 0,0057 & 0,019 & 0,0063 & 0,021 \\
\hline
\end{tabular}

\subsection{Statistical analysis}

Descriptive statistical operations like mean, median (med), minimum (min), maximum (max), and Skewness test were applied for the analysis of the measured data. Pearson's correlation with 
significance level of $\mathrm{p}$-value: $\mathrm{p}<0.05, \mathrm{p}<0.01$, and $\mathrm{p}<0.001$ was used. Factor analysis (principal component analysis) and cluster analysis for PAHs components were applied for getting the qualitative information of the source of the 16 components of PAHs. Excel 2016 and JASP v0.8.5.1 software tools were used for statistical data processing.

\subsection{Ecological Risk of PAHs in Soils and Groundwater}

A risk quotient $\left(\mathrm{RQ}\left(\mathrm{RQ}_{(\mathrm{NCS})}\right.\right.$ and $\left.\left.\mathrm{RQ} \mathrm{Q}_{(\mathrm{MPC} S)}\right)\right)$ was used to assess the ecological risk of PAHs. The maximum permissible concentrations (MPCs) (concentrations of PAHs above which the risk of adverse effects is considered unacceptable) and negligible concentrations (NCs) (MPC/100) of PAHs in soils and groundwater were used, according to the research of Kalf et al. [40], Wang et al. [3] and Lan et al. [41].

$\mathrm{RQ}_{(\mathrm{NCS})}$ and $\mathrm{RQ}_{(\mathrm{MPCS})}$ were defined as follows $[3,41]$ :

$$
\begin{aligned}
& \mathrm{RQNCs}_{\mathrm{NC}}=\mathrm{CPAHs}_{\mathrm{P}} / \mathrm{CQV}_{\mathrm{N}(\mathrm{NCS})} \\
& R_{\mathrm{MPCs}}=\mathrm{C}_{\mathrm{PAHs}} / \mathrm{C}_{\mathrm{QV}} \text { (MPCs) }
\end{aligned}
$$

where $R Q_{N C s}$ and $R Q_{M P C s}$ were risk quotient values $\left(R_{(N C s)}\right.$ and $\left.R_{(M P S)}\right), C_{P A H s}$ was the PAHs measured concentration in the soil and groundwater and values $\mathrm{C}_{\mathrm{Qv}}\left(\mathrm{C}_{(\mathrm{NCS})}\right.$ and $\left.\left.\mathrm{C}_{(\mathrm{MPC})}\right)\right)$ were the corresponding quality values of PAHs in the soil and groundwater. Table 3. shows the ecological risk classification of PAHs and $\mathrm{PAAHs}$, according to the research of Lan et al. [41]

\begin{tabular}{|c|c|c|c|c|c|}
\hline \multicolumn{3}{|c|}{ Individual PAHs } & \multicolumn{3}{|c|}{ इPAHs } \\
\hline $\mathbf{R Q}_{(\mathrm{NCs})}$ & $R Q_{(\mathrm{MPC})}$ & Risk rank & Risk rank & $\mathbf{R Q}_{(\mathrm{NCS})}$ & $\mathbf{R Q}_{\text {(MPCs) }}$ \\
\hline \multirow[t]{2}{*}{0} & & Risk-free & Risk-free & 0 & \\
\hline & & & Low risk & $\geq 1,<800$ & 0 \\
\hline \multirow{3}{*}{$\geq 1$} & $<1$ & Moderate risk & Moderate risk 1 & $\geq 800$ & 0 \\
\hline & & & Moderate risk 2 & $<800$ & $\geq 1$ \\
\hline & $\geq 1$ & High-risk & High-risk & $\geq 800$ & $\geq 1$ \\
\hline
\end{tabular}

Table 3. Risk classification of individual PAHs and $\sum 16 \mathrm{PAHs}[41,3]$.

\section{Results and Discussion}

\subsection{Basic Characteristics of PAHs Concentrations in Soils and Groundwater}

Table 4 shows the descriptive statistics of the 16 priority PAHs compounds in contaminated soils (at a depth of up to $30 \mathrm{~cm}$ (surface layer), $100 \mathrm{~cm}, 200 \mathrm{~cm}, 300 \mathrm{~cm}$, and $400 \mathrm{~cm}$ ) and groundwater environmental samples in four locations of the examined area. In this research, the $\Sigma 16 \mathrm{PAHs}$ in the soil (at a depth of up to $30 \mathrm{~cm}, 100 \mathrm{~cm}, 200 \mathrm{~cm}, 300 \mathrm{~cm}, 400 \mathrm{~cm}$ ) ranged from 0.99 to $2.24 \mathrm{mg} / \mathrm{kg}$, from 0.34 to 0.46 , from 0.24 to 0.32 , from 0.13 to 0.27 and from 0.13 to 0.47 , with mean values of $1.70 \mathrm{mg} / \mathrm{kg}$, $0.40 \mathrm{mg} / \mathrm{kg}, 0.28 \mathrm{mg} / \mathrm{kg}, 0.20 \mathrm{mg} / \mathrm{kg}$ and $0.26 \mathrm{mg} / \mathrm{kg}$, respectively. The $\sum 16 \mathrm{PAHs}$ in groundwater ranged from 0.23 to $4.50 \mathrm{mg} / \mathrm{m}^{3}$, with a mean value of $1.42 \mathrm{mg} / \mathrm{m}^{3}$. According to the national standards [37], the concentrations of $\sum 16 \mathrm{PAHs}$ found in this study are higher in one location and lower in other locations than the permissible value of $2 \mathrm{mg} / \mathrm{kg}$ in agricultural soils. The soil is heavily contaminated (heavily polluted) according to permissible limits of $1 \mathrm{mg} / \mathrm{kg}$ [42] in a surface layer of soil $(0-30 \mathrm{~cm})$ and contamination in soils was 1-2.24 times higher than limits. 
6 of 19

Table 4. Descriptive statistics of the PAHs in different layers of soils and groundwater.

\begin{tabular}{|c|c|c|c|c|c|c|c|c|c|c|c|c|c|c|c|c|c|c|}
\hline \multirow{3}{*}{ PAHs } & \multicolumn{15}{|c|}{ Soil (mg/kg) } & \multirow{2}{*}{\multicolumn{3}{|c|}{$\begin{array}{c}\text { Groundwater } \\
\left(\mathrm{mg} / \mathrm{m}^{3}\right)\end{array}$}} \\
\hline & \multicolumn{3}{|c|}{$30 \mathrm{~cm}$} & \multicolumn{3}{|c|}{$100 \mathrm{~cm}$} & \multicolumn{3}{|c|}{$200 \mathrm{~cm}$} & \multicolumn{3}{|c|}{$300 \mathrm{~cm}$} & \multicolumn{3}{|c|}{$400 \mathrm{~cm}$} & & & \\
\hline & Mean & Med & Range & $\begin{array}{c}\text { Mea } \\
\mathbf{n}\end{array}$ & Med & Range & $\begin{array}{c}\text { Mea } \\
\text { n }\end{array}$ & Med & Range & $\begin{array}{l}\text { Me } \\
\text { an }\end{array}$ & Med & Range & $\begin{array}{c}\text { Me } \\
\text { an }\end{array}$ & Med & Range & $\begin{array}{l}\text { Me } \\
\text { an }\end{array}$ & $\begin{array}{c}\mathrm{Me} \\
\mathrm{d}\end{array}$ & Range \\
\hline $\mathrm{BbF}$ & 0.14 & 0.14 & $0.08-0.20$ & 0.04 & 0.04 & n.d.-0.07 & 0.02 & 0.01 & n.d.-0.06 & 0.02 & 0.01 & n.d.-0.05 & 0.01 & 0.02 & $0.00-0.03$ & - & - & n.d.-n.d. \\
\hline BkF & 0.24 & 0.28 & $0.07-0.32$ & 0.01 & 0.01 & $0.01-0.02$ & 0.01 & 0.00 & n.d.- -0.03 & 0.01 & 0.01 & n.d.- -0.01 & 0.01 & 0.00 & n.d.- 0.04 & - & - & n.d.-n.d. \\
\hline $\mathrm{BaP}$ & 0.09 & 0.05 & $0.02-0.24$ & 0.06 & 0.06 & $0.05-0.06$ & 0.03 & 0.03 & $0.01-0.04$ & 0.02 & 0.01 & n.d.-0.04 & 0.03 & 0.04 & $0.01-0.04$ & - & - & n.d.-n.d. \\
\hline BghiP & 0.15 & 0.15 & $0.03-0.28$ & 0.01 & 0.01 & n.d.-0.01 & 0.01 & 0.00 & n.d.-0.02 & 0.00 & 0.00 & n.d.-0.01 & 0.03 & 0.02 & n.d.- 0.06 & 0.02 & 0.00 & n.d.-0.09 \\
\hline IcdP & 0.02 & 0.02 & n.d.- -0.05 & 0.01 & 0.01 & n.d.- -0.02 & 0.01 & 0.01 & n.d.- -0.02 & 0.01 & 0.01 & $0.01-0.02$ & 0.04 & 0.02 & n.d.- 0.09 & - & - & n.d.-n.d. \\
\hline Ant & 0.20 & 0.25 & $0.01-0.30$ & 0.02 & 0.02 & $0.02-0.03$ & 0.02 & 0.02 & n.d.-0.04 & 0.01 & 0.01 & n.d.-0.03 & 0.03 & 0.02 & $0.02-0.07$ & 0.02 & 0.00 & n.d. -0.07 \\
\hline Chr & 0.06 & 0.05 & 0.03-0.09 & 0.03 & 0.03 & $0.02-0.03$ & 0.02 & 0.02 & $0.01-0.03$ & 0.02 & 0.02 & $0.01-0.03$ & 0.03 & 0.02 & $0.01-0.04$ & 0.07 & 0.01 & n.d.- 0.26 \\
\hline DahA & 0.38 & 0.38 & $0.29-0.48$ & - & - & n.d.-n.d. & 0.00 & 0.00 & n.d.-0.01 & - & - & n.d.-n.d. & 0.01 & 0.01 & n.d.- 0.03 & 0.15 & 0.03 & n.d. -0.57 \\
\hline Acy & 0.11 & 0.10 & $0.02-0.21$ & 0.01 & 0.01 & n.d.-0.03 & 0.04 & 0.04 & n.d.-0.06 & - & - & n.d.-n.d. & 0.00 & 0.00 & n.d.- 0.01 & 0.17 & 0.12 & $0.02-0.44$ \\
\hline Pyr & 0.03 & 0.02 & $0.01-0.08$ & - & - & n.d.-n.d. & 0.02 & 0.02 & n.d.-0.04 & 0.00 & 0.00 & n.d.- -0.01 & 0.01 & 0.00 & n.d.- 0.02 & 0.13 & 0.01 & n.d. -0.50 \\
\hline $\mathrm{BaA}$ & 0.06 & 0.07 & n.d. -0.10 & 0.03 & 0.03 & $0.02-0.05$ & 0.02 & 0.01 & n.d.-0.04 & 0.03 & 0.03 & $0.01-0.05$ & 0.00 & 0.01 & n.d.- 0.01 & 0.17 & 0.03 & $0.01-0.62$ \\
\hline Phe & 0.04 & 0.04 & n.d.-0.09 & 0.05 & 0.05 & $0.03-0.07$ & 0.05 & 0.05 & $0.04-0.06$ & 0.03 & 0.02 & $0.01-0.06$ & 0.03 & 0.02 & n.d.- 0.07 & 0.23 & 0.02 & n.d. -0.87 \\
\hline Flo & 0.11 & 0.06 & $0.01-0.30$ & 0.04 & 0.04 & $0.04-0.04$ & 0.02 & 0.02 & $0.01-0.04$ & 0.02 & 0.02 & n.d.-0.03 & 0.01 & 0.01 & $0.01-0.02$ & 0.16 & 0.05 & n.d. -0.56 \\
\hline Nap & 0.03 & 0.03 & $0.01-0.07$ & 0.03 & 0.03 & $0.03-0.03$ & 0.01 & 0.01 & n.d.-0.02 & 0.00 & 0.00 & n.d.-0.01 & 0.01 & 0.00 & n.d.- 0.02 & 0.19 & 0.06 & $0.02-0.64$ \\
\hline Ace & 0.02 & 0.02 & $0.01-0.03$ & 0.01 & 0.01 & $0.01-0.01$ & 0.01 & 0.01 & n.d.- -0.02 & 0.00 & 0.00 & n.d.- -0.01 & 0.00 & 0.00 & n.d.- 0.01 & 0.07 & 0.03 & $0.02-0.20$ \\
\hline Fluo & 0.02 & 0.02 & n.d.-0.02 & 0.05 & 0.05 & $0.05-0.05$ & 0.01 & 0.00 & n.d.-0.02 & 0.02 & 0.00 & n.d.-0.05 & 0.00 & 0.01 & n.d.- 0.01 & 0.04 & 0.01 & n.d.-0.16 \\
\hline $\begin{array}{c}\sum 16 \\
\text { PAHs }\end{array}$ & 1.70 & 1.79 & $0.99-2.24$ & 0.40 & 0.40 & $0.34-0.46$ & 0.28 & 0.28 & $0.24-0.32$ & 0.20 & 0.19 & $0.13-0.27$ & 0.26 & 0.19 & $0.13-0.47$ & 1.42 & 0.69 & $0.23-4.50$ \\
\hline $\mathrm{pH}$ & 6.45 & 6.25 & $5.60-7.70$ & 7.66 & 7.66 & $7.37-7.94$ & 7.72 & 7.73 & 7.43-7.99 & 7.82 & 7.87 & $7.51-8.08$ & 7.95 & 7.91 & 7.87-8.07 & - & - & - \\
\hline Hum. & 1.65 & 1.30 & $0.00-4.00$ & 1.53 & 1.53 & $0.82-2.24$ & 1.11 & 0.74 & $0.53-2.42$ & 0.83 & 0.82 & $0.75-0.93$ & 0.74 & 0.75 & $0.72-0.76$ & - & - & - \\
\hline
\end{tabular}


The $\sum 16$ PAHs in groundwater ranged from 0.23 to $4.50 \mathrm{mg} / \mathrm{m}^{3}$, with a mean value of $1.41 \mathrm{mg} / \mathrm{m}^{3}$. The measured value indicates that groundwater is highly polluted and that groundwater is classified in the fifth class of water quality, and those are heavily polluted waters that can be used for almost no purpose. [38]. Among the $\sum 16 \mathrm{PAHs}$, the three most abundant were Phe $\left(0.87 \mathrm{mg} / \mathrm{m}^{3}\right)$, Nap $(0.64$ $\left.\mathrm{mg} / \mathrm{m}^{3}\right)$ and $\mathrm{BaA}\left(0.62 \mathrm{mg} / \mathrm{m}^{3}\right)$.

The $\sum 16 \mathrm{PAHs}$ are the highest in the surface layer of soil, and with increasing the depth it decreases. Similar results were also observed in Shenyang City in China, where the PAH concentrations decreased with the depth of the soil [43]. Jiao et al., 2017 [44] came up with a similar result of decreasing concentration of $\Sigma 16 \mathrm{PAHs}$ by increasing the depth in the study (Shanxi, China) and explained that PAHs come from pyrolysis inputs due to industrial emissions in the industrial activities and also shows the migrate trend of PAHs in the vertical section of the soils [44]. Comparing the concentrations of $\sum$ PAHs in soils in the Loess Plateau, China, similar values were obtained in the surface layer of soil [3], in an urban location in China [6], 6 times higher than values in the Hunpu region, a wastewater-irrigated area, Shenyang City, China [43]. Values of PAHs in locations are higher than values along the Govan to Clydebank corridor, the area with a history of heavy industry (concentrations range from $86.9-653 \mathrm{mg} / \mathrm{kg}$ ) [45], similar as in examined locality. Values are 10 times lower than values in Glasgow soils and 2 times higher than values in Ljubljana and Torino soils [4].

The distribution of the 2, 3-ring, 4-ring (low molecular) and 5, 6-ring (high molecular) PAHs are shown in Figure 2. The PAHs frequency in surface soils $(0-30 \mathrm{~cm})$ was detected as 2, 3, 4-rings $(40 \%)$ and 5-ring $(60 \%)$. The highest proportions of high molecular PAHs (5, 6-rings) are found at depths of $30 \mathrm{~cm}$ and $400 \mathrm{~cm}$, while in the water they are very small. The percentage representation of low molecular PAHs (2, 3, 4-rings) was highest in groundwater.

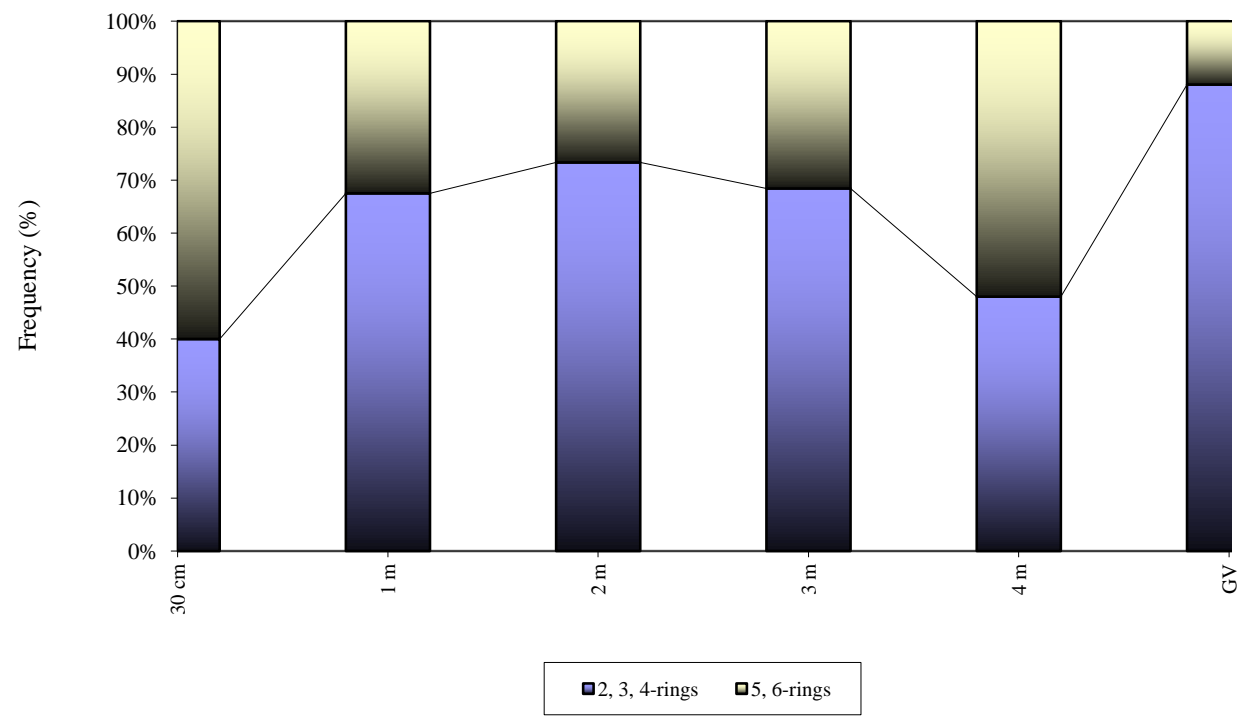

Figure 2. Frequency of PAHs per ring in soil and groundwater for high and low molecular PAHs.

\subsection{Correlation analysis of PAHs and soil properties}

Tables 5 and 6 present the correlation analysis (Pearson correlation test). Table 5 presents correlations between the determined PAHs values in the surface layer of soil in each location and PAHs values per different soil layers and groundwater. Table 6 shows the correlation analysis for PAHs components $(\mathrm{p}<0.05, \mathrm{p}<0.00)$ ( $\mathrm{p}$ - Pearson's rank correlation). Bolded numbers indicate a statistically significant correlation $(r>0.5)$.

The results of the correlation analysis between the PAHs values of surface soil in each location and PAHs values in soil layers and ground water are considered to have a strong positive statistically significant correlation ( $r>0.5)$. Correlation with PAHs values in groundwater is weak, which confirms that the site soil is not the only cause of groundwater pollution. An additional source of pollution may be from other polluted sites, which have reached the site via groundwater flow. 
Table 5. Correlation per layers of soil and groundwater.

\begin{tabular}{|c|c|c|c|c|c|}
\hline \multirow[b]{3}{*}{ S1 Surface layer } & \multirow[b]{3}{*}{-} & \multirow[b]{3}{*}{$\mathrm{S} 1100 \mathrm{~cm}$} & \multicolumn{3}{|c|}{ Pearson's correlation } \\
\hline & & & \multicolumn{2}{|c|}{$\mathbf{r}$} & \multirow{2}{*}{$\frac{\mathbf{p}}{<.001}$} \\
\hline & & & 0.977 & $* * *$ & \\
\hline S1 Surface layer & - & $S 1200 \mathrm{~cm}$ & 0.922 & $* * *$ & $<.001$ \\
\hline S1 Surface layer & - & S1 $300 \mathrm{~cm}$ & 0.931 & $* * *$ & $<.001$ \\
\hline S1 Surface layer & - & $\mathrm{S} 1400 \mathrm{~cm}$ & 0.921 & $* * *$ & $<.001$ \\
\hline S1 Surface layer & - & S1 Groundwater & 0.143 & & 0.598 \\
\hline S2 Surface layer & - & $\mathrm{S} 2100 \mathrm{~cm}$ & 0.991 & $* * *$ & $<.001$ \\
\hline S2 Surface layer & - & S2 $200 \mathrm{~cm}$ & 0.995 & $* * *$ & $<.001$ \\
\hline S2 Surface layer & - & S2 $300 \mathrm{~cm}$ & 0.993 & $* * *$ & $<.001$ \\
\hline S2 Surface layer & - & S2 Groundwater & 0.619 & $*$ & 0.011 \\
\hline S3 Surface layer & - & S3 $200 \mathrm{~cm}$ & 0.949 & $* * *$ & $<.001$ \\
\hline S3 Surface layer & - & S3 $300 \mathrm{~cm}$ & 0.992 & $* * *$ & $<.001$ \\
\hline S3 Surface layer & - & S3 $400 \mathrm{~cm}$ & 0.993 & $* * *$ & $<.001$ \\
\hline S3 Surface layer & - & S3 Groundwater & -0.061 & & 0.824 \\
\hline S4 Surface layer & - & $\mathrm{S} 4200 \mathrm{~cm}$ & 0.966 & $* * *$ & $<.001$ \\
\hline S4 Surface layer & - & $\mathrm{S} 4400 \mathrm{~cm}$ & 0.965 & $* * *$ & $<.001$ \\
\hline S4 Surface layer & - & S4 Groundwater & -0.329 & & 0.214 \\
\hline
\end{tabular}

Correlations of Nap with Acy, Ace, Flo, Ant, and Pyr; Acy with Ant and Pyr; Ace with Flo and Ant; Flo with Ant; Ant with Pyr; Fluo with BaA, Chr, BbF and BkF; Fluo with BaP, IcdP, DahA and BghiP; BaA with Chr, BbF, BkF, BaP, IcdP, DahA and BghiP; Chr with BbF, BkF, BaP, IcdP, DahA and BghiP; BbF with BkF, BaP, IcdP, DahA and BghiP; BkF with BaP, IcdP, DahA and BghiP, BaP with IcdP, DahA and BghiP; IcdP with DahA and BghiP; DahA with BghiP are strong positive correlations. These results suggest that these pollutant pairs might have similar sources or result from similar factors.

Table 6. Correlation per PAHs components of soil and groundwater.

\begin{tabular}{|c|c|c|c|c|c|c|c|c|c|c|c|c|c|}
\hline \multicolumn{14}{|c|}{ Pearson's correlation test ( $\mathrm{r}$ and $\mathrm{p}$ values) } \\
\hline Nap - & Acy & 0.679 & $* * *$ & $<.001$ & Ace & - DahA & -0.145 & & 0.543 & Fluo & - $\mathrm{BaP}$ & 0.862 & $* * *<.001$ \\
\hline Nap - & Ace & 0.726 & $* * *$ & $<.001$ & Ace & - BghiP & 0.005 & & 0.982 & Fluo & - IcdP & 0.919 & $* * *<.001$ \\
\hline Nap - & Flo & 0.761 & $* * *$ & $<.001$ & Flo & - Phe & 0.490 & * & 0.028 & Fluo & - DahA & 0.900 & $* * *<.001$ \\
\hline Nap - & Phe & 0.249 & & 0.290 & Flo & Ant & 0.775 & $* * *$ & $<.001$ & Fluo & - BghiP & 0.852 & $* * *<.001$ \\
\hline Nap - & Ant & 0.696 & $* * *$ & $<.001$ & Flo & - Fluo & & & & Pyr & - $\mathrm{BaA}$ & 0.133 & 0.575 \\
\hline Nap - & Fluo & 0.155 & & 0.514 & Flo & - Pyr & 0.453 & $*$ & 0.045 & Pyr & - Chr & -0.011 & 0.964 \\
\hline Nap - & Pyr & 0.556 & * & 0.011 & Flo & - $\mathrm{BaA}$ & 0.431 & & 0.058 & Pyr & $\mathrm{BbF}$ & 0.017 & 0.943 \\
\hline Nap - & $\mathrm{BaA}$ & 0.120 & & 0.613 & Flo & Chr & 0.270 & & 0.249 & Pyr & $\mathrm{BkF}$ & & 0.738 \\
\hline Nap - & Chr & -0.068 & & 0.775 & Flo & $\mathrm{BbF}$ & 0.297 & & 0.203 & Pyr & $\mathrm{BaP}$ & 0.205 & 0.386 \\
\hline Nap - & $\mathrm{BbF}$ & -0.036 & & 0.882 & Flo & $\mathrm{BkF}$ & & & & Pyr & - IcdP & 0.017 & 0.944 \\
\hline Nap - & $\mathrm{BkF}$ & -0.161 & & 0.498 & Flo & $\mathrm{BaP}$ & & * & 0.034 & Pyr & - DahA & 0.047 & 0.845 \\
\hline Nap - & $\mathrm{BaP}$ & 0.103 & & 0.664 & Flo & - IcdP & 0.222 & & 0.347 & Pyr & - BghiP & -0.081 & 0.735 \\
\hline Nap - & IcdP & -0.111 & & 0.641 & Flo & - DahA & & & & & & 0.841 & $* * *<.001$ \\
\hline Nap - & - DahA & -0.112 & & 0.639 & Flo & - BghiP & 0.203 & & 0.390 & $\mathrm{BaA}$ & $\mathrm{BbF}$ & 0.851 & $* * *<.001$ \\
\hline Nap - & - BghiP & -0.030 & & 0.901 & Phe & - Ant & 0.380 & & 0.098 & $\mathrm{BaA}$ & $\mathrm{BkF}$ & 0.810 & $* * *<.001$ \\
\hline Acy - & Ace & 0.171 & & 0.470 & Phe & - Fluo & 0.012 & & 0.959 & $\mathrm{BaA}$ & $\mathrm{BaP}$ & 0.780 & $* * *<.001$ \\
\hline Acy - & Flo & 0.411 & & 0.071 & Phe & - Pyr & 0.059 & & 0.804 & $\mathrm{BaA}$ & IcdP & 0.835 & $* * *<.001$ \\
\hline
\end{tabular}




\begin{tabular}{|c|c|c|c|c|c|c|c|c|c|c|c|c|c|}
\hline Acy & Phe & 0.140 & & 0.557 & Phe & $\mathrm{BaA}$ & -0.098 & & 0.680 & $\mathrm{BaA}$ & - DahA & 0.873 & $* * *<.001$ \\
\hline Acy & Ant & 0.649 & $* *$ & 0.002 & Phe & Chr & -0.090 & & 0.706 & $\mathrm{BaA}$ & - BghiP & 0.698 & $* * *<.001$ \\
\hline Acy & - Fluo & 0.086 & & 0.719 & Phe & $\mathrm{BbF}$ & -0.105 & & 0.659 & Chr & - $\mathrm{BbF}$ & 0.984 & $* * *<.001$ \\
\hline Acy & Pyr & 0.699 & $* * *$ & $<.001$ & Phe & $\mathrm{BkF}$ & -0.178 & & 0.454 & Chr & - $B k F$ & 0.978 & $* * *<.001$ \\
\hline Acy & $\mathrm{BaA}$ & 0.036 & & 0.879 & Phe & $\mathrm{BaP}$ & 0.007 & & 0.976 & Chr & $\mathrm{BaP}$ & 930 & $* * *<$ \\
\hline Acy & Chr & -0.047 & & 0.843 & Phe & - IcdP & -0.156 & & 0.511 & Chr & - IcdP & 0.983 & $* * *<.001$ \\
\hline Acy & $-\mathrm{BbF}$ & -0.045 & & 0.851 & Phe & - DahA & -0.198 & & .403 & Chr & - DahA & 962 & $* * *<.001$ \\
\hline Acy & $\mathrm{BkF}$ & -0.097 & & 0.683 & Phe & - BghiP & -0.108 & & 0.050 & Chr & - BghiP & 0.858 & $* * *<.001$ \\
\hline Acy & $\mathrm{BaP}$ & 0.116 & & 0.625 & Ant & - Fluo & 0.254 & & 0.280 & $\mathrm{BbF}$ & - $B k F$ & 0.975 & $* * *<.001$ \\
\hline Acy & - IcdP & -0.098 & & 0.680 & Ant & Pyr & 0.613 & $* *$ & 0.004 & $\mathrm{BbF}$ & - $\mathrm{BaP}$ & 0.931 & $* * *<.001$ \\
\hline Acy & - DahA & -0.056 & & .815 & Ant & - $\mathrm{BaA}$ & 345 & & & $\mathrm{BbF}$ & - IcdP & & $* * *<$ \\
\hline Acy & - BghiP & -0.098 & & 0.681 & Ant & Chr & 0.135 & & 0.569 & $\mathrm{BbF}$ & - DahA & 0.968 & $* * *<.001$ \\
\hline Ace & - Flo & 0.765 & $* * *$ & $<.001$ & Ant & $\mathrm{BbF}$ & 0.175 & & 0.461 & $\mathrm{BbF}$ & - BghiP & 0.909 & $* * *<.001$ \\
\hline Ace & - Phe & 0.401 & & 0.079 & Ant & $\mathrm{BkF}$ & 0.078 & & 0.744 & $\mathrm{BkF}$ & - $\mathrm{BaP}$ & 0.874 & $* * *<.001$ \\
\hline Ace & Ant & 0.532 & * & 0.016 & Ant & $\mathrm{BaP}$ & 0.327 & & 0.159 & $\mathrm{BkF}$ & - IcdP & 0.974 & $* * *<.001$ \\
\hline Ace & - Fluo & 0.149 & & 0.531 & Ant & - IcdP & 0.079 & & 0.740 & $\mathrm{BkF}$ & - DahA & 0.955 & $* * *<.001$ \\
\hline Ace & - Pyr & 0.227 & & 0.337 & Ant & - DahA & 0.105 & & 0.659 & $\mathrm{BkF}$ & - BghiP & 0.879 & $* * *<.001$ \\
\hline Ace & - $\mathrm{BaA}$ & 0.144 & & 0.545 & Ant & - BghiP & 0.115 & & 0.629 & $\mathrm{BaP}$ & - IcdP & 0.917 & $* * *<.001$ \\
\hline Ace & - Chr & -0.100 & & 0.675 & Fluo & - Pyr & 0.039 & & 0.871 & $\mathrm{BaP}$ & - DahA & 0.897 & $* * *<.001$ \\
\hline Ace & - $\mathrm{BbF}$ & -0.047 & & 0.844 & Fluo & $\mathrm{BaA}$ & 0.857 & $* * *$ & $<.001$ & $\mathrm{BaP}$ & - BghiP & 0.817 & $* * *<.001$ \\
\hline Ace & - $B k F$ & -0.164 & & 0.490 & Fluo & Chr & 0.935 & $* * *$ & $<.001$ & IcdP & - DahA & 0.982 & $* * *<.001$ \\
\hline Ace & - $\mathrm{BaP}$ & 0.012 & & 0.960 & Fluo & $\mathrm{BbF}$ & 0.941 & $* * *$ & $<.001$ & IcdP & - BghiP & 0.884 & $* * *<.001$ \\
\hline Ace & - IcdP & -0.109 & & 0.646 & Fluo & - $B k F$ & 0.919 & $* * *$ & $<.001$ & DahA & - BghiP & 0.865 & $* * *<.001$ \\
\hline
\end{tabular}

Due to hydrophobicity and non-polarity PAHs merge with soil organic matter (SOM) or humus colloids in soil [45]. SOM plays the role of PAHs carrier for downward migration and protects PAHs from the degradation. Fine particle clays have a larger specific surface area or have more adsorption sites, showing a higher sorption capacity of PAH compared to fine or coarse sand [28].

SOM has a high sorption capacity, limiting PAHs to the upper part of the soil profile thereby reducing the concentration of PAHs with the depth. Organic matter is of great importance for the sorption of hydrophobic organic compounds (among other things PAHs). Its content is higher than $8 \%$ while the combined effect of organic matter and clay mineral is manifested at its content below $6 \%[46]$.

The physical and chemical composition of the soil is responsible for retaining PAHs in soil. The quantities of organic $C$ and hydrophobicity of organic matter in soil are estimated as the most important parameter for PAH retention in the environment $[48,15]$.

Correlation analysis between $\sum 16 \mathrm{PAHs}$, humus (organic matter) and $\mathrm{pH}$ in soil was conducted in the present study (Table 7).

Table 7. Correlation analysis between $\sum 16 \mathrm{PAHs}$, humus and $\mathrm{pH}$.

\begin{tabular}{|c|c|c|}
\hline & Pearson's $\mathbf{r}$ & p \\
\hline$\sum 16$ PAHs - $\quad p H$ & $-0.655^{* *}$ & 0.006 \\
\hline$\overline{\sum 16 \text { PAHs - Humus }}$ & 0.361 & 0.170 \\
\hline pH - Humus & 0.179 & 0.507 \\
\hline
\end{tabular}

A statistically moderate negative correlation was found between $\sum 16 \mathrm{PAHs}$ and $\mathrm{pH}$. The value of $\mathrm{r}$ is -0.655 ( $\mathrm{p}$-value is 0.01 ). The significant correlation between $\sum 16 \mathrm{PAH}$ and humus has not been determined in the study. There is probably a lasting input of fresh PAHs (from the biomass heating 
plant in close proximity as well as the traffic) which confirms the correlation. Nam et al. [50] obtained similar results.

\subsection{Factor, Principal Components and Cluster Analysis}

Factor and principal components analysis (FA and PCA) are multivariate statistical methods to identify the main factors that determine the variability of environmental quality [51].

The relationship between the components of PAHs levels in soils and groundwater with anthropogenic activities was examined, using FA. FA was used to determine the effective variable factors (compounds). The varimax rotation was used for component loading for PAHs components in soil and groundwater (Table 8). The aim of FA was to create a fewer number of factors by combining two or more variables. The primary output for a PCA shows the correlation between each variable of a principal component and the variable factors (PC1, PC2, and PPC3), i.e. elements in soil samples are affected by two major components. Three principal components (PC) have eigenvalues higher than 1 (PC1, PC2, and PC3) (Table 7).

Table 8. Component loading for PAHs components in soil and groundwater, according to factor analysis.

\begin{tabular}{ccccc}
\hline & PC 1 & PC 2 & PC 3 & Uniqueness \\
\hline Ace & $\cdot$ &. & $\mathbf{0 . 8 7 4}$ & 0.197 \\
Acy &. & $\mathbf{0 . 9 0 6}$ &. & 0.171 \\
Ant &. & 0.702 & 0.531 & 0.195 \\
BaA & $\mathbf{0 . 8 7 5}$ &. &. & 0.198 \\
BaP & $\mathbf{0 . 9 3 0}$ &. &. & 0.094 \\
BbF & $\mathbf{0 . 9 9 6}$ &. &. & 0.009 \\
BghiP & $\mathbf{0 . 9 0 4}$ &. &. & 0.175 \\
BkF & $\mathbf{0 . 9 7 7}$ &. &. & 0.027 \\
Chr & $\mathbf{0 . 9 8 7}$ &. &. & 0.024 \\
DahA & $\mathbf{0 . 9 7 9}$ &. &. & 0.025 \\
Flo &. &. & $\mathbf{0 . 7 9 6}$ & 0.072 \\
Fluo & $\mathbf{0 . 9 4 8}$ &. &. & 0.067 \\
IcdP & $\mathbf{0 . 9 8 9}$ &. &. & 0.014 \\
Nap &. & 0.690 & 0.587 & 0.178 \\
Phe &. &. & 0.741 & 0.436 \\
Pyr &. & 0.895 &. & 0.198 \\
Eigenvalue & 8.38 & 4.18 & 1.35 & \\
Variance (\%) & 52.39 & 26.14 & 8.46 & \\
Total variance & 52.39 & 78.53 & 86.99 & \\
(Cum \%) & & & & \\
\hline
\end{tabular}

The RC1 factor included BaA, BaP, BbF, BghiP, BkF, Chr, DahA, Fluo and IcdP was identified according to their coefficients in the component matrix. The PC1 factor is in relation to coal combustion, i.e. burning and vehicular emissions and was indicative of the pyrogenic origin, specially Fla, Pyr, BaA, BbF, BkF, BaP, BghiP, and IcdP [52]. According to Liu et al. [53], all components were strong positively loaded if values were $>0.75$, and moderately loaded if values were in the range from 0.75-0.5 (Table 7). Harrison et al. [54] reported that compounds Fluo, BaA, and Chr were typical markers for coal combustion. The PC1 factor explained $52.39 \%$ of the total variance. Davis et al. [56] also reported that BghiP and IcdP sources were from the vehicular exhaust. According to Iwegbue et al. [55] Chr, BkF and DahA are indicators of diesel emissions and origin of BghiP and IcdP are the combustion of heavy oil. 
The PC2 factor that includes Acy, Ant, Nap and Pyr was identified as well, and it explains 26.14\% of the total variance. This factor is of petrogenic origin. Acy component was strong positively loaded (>0.75) [53] (Table 7). Furthermore, Davis et al. [56] pointed out that Acy is the main product of a petroleum source. Ant and Pyr were also strong positively loaded, if the value were $>0.70$ [57]. Nap acts as a marker for petroleum source [58] as well as for mineral oils [52]. The petrogenic source is probably directly contaminated from illegal waste disposal and petroleum leak in location and characterized by the predominance of 2- or 3-ring PAHs.

The PC3 factor includes components that were strong positively loaded Ace, Flo $(>0.75)$ and Phe $(>0.70)[53,57]$. Ant and Nap were moderately loaded, as their values ranged from $0.75-0.5$. This factor contains 3- and 4-ring PAH compounds of biomass origin and explains $8.46 \%$ of the total variance. Loadings of Phe and Ant were higher and represent low-temperature processes of wood/biomass combustion, i.e. the incomplete combustion of wood/biomass [56]. Zeng et al. [6] explained that the Flo compounds were characteristic of coal combustion. The probable cause is a wood-burning plant nearby.

Three components accounted for $86.99 \%$ of the total variance, highlighting the major trends of the soil ecosystem. The source analysis of soil PAHs demonstrated that the main causes of PAHs are coal combustion (pyrogenic) (PC1 factor), petroleum sources (petrogenic) (PC2 factor) and biomass combustion (PC3 factor).

PCA provides information on the most significant parameters [59]. Figure 3a shows which PCA is done to combine measured variables in three components, PC1, PC2, and PC3. The direction of the arrows shows that variables, i.e. PAHs components (Ace, Acy, Ant, BaA, BaP, BbF, BghiP, BkF, Chr, DahA, Flo, Fluo, IcdP Nap, Phe, and Pyr) contribute to the three variable factors.

The weights to emphasize are BaA, BaP, BbF, BghiP, BkF, Chr, DahA, Fluo and IcdP (for PC1), Acy, Nap and Pyr (for PC2) and Phe, Flo, and Ace (for PC3) variables that stand out more than others.

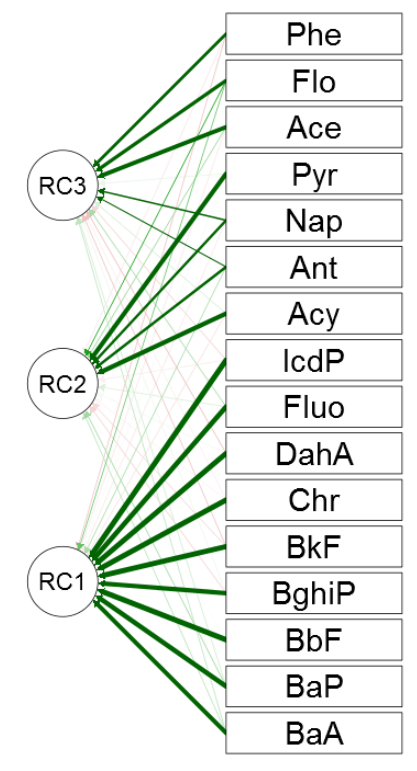

(a)

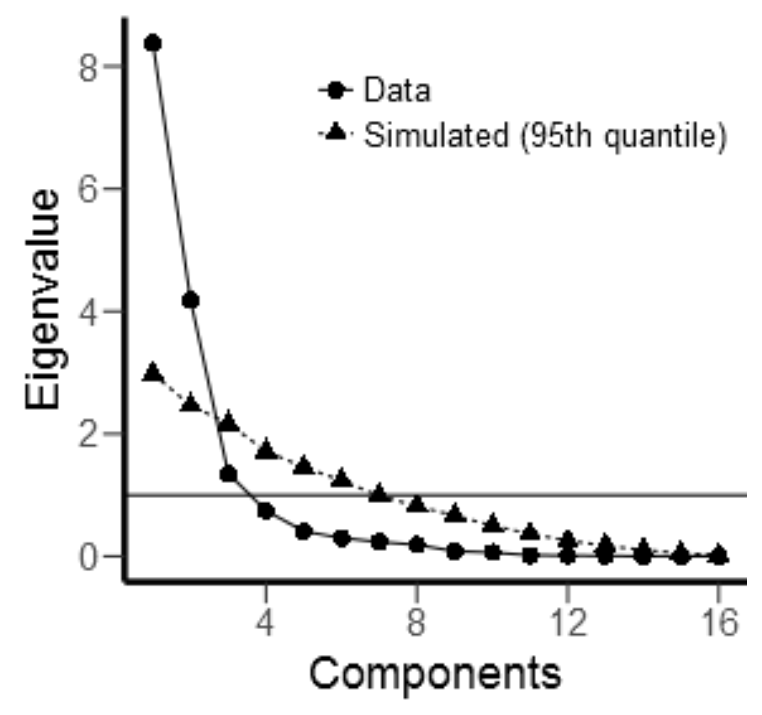

(b)

Figure 3. (a) Path diagram (b); Scree plot.

Figure $3 b$ shows PCA scree plot (varimax rotation) with eigenvalue values higher than one, as a criterion for evaluating the components required to explain the origin of variance in the data. Three factors explained $86.99 \%$ of the data in total variance.

The hierarchical cluster analysis (CA), an analytical technique for multivariate data analysis [51] was applied to the data, and the Paired group (UPGMA) method distance was chosen for calculation (Figure 4). CA was performed to check the results of the PC analysis and provided details of similarities between groups of parameters [60]. 


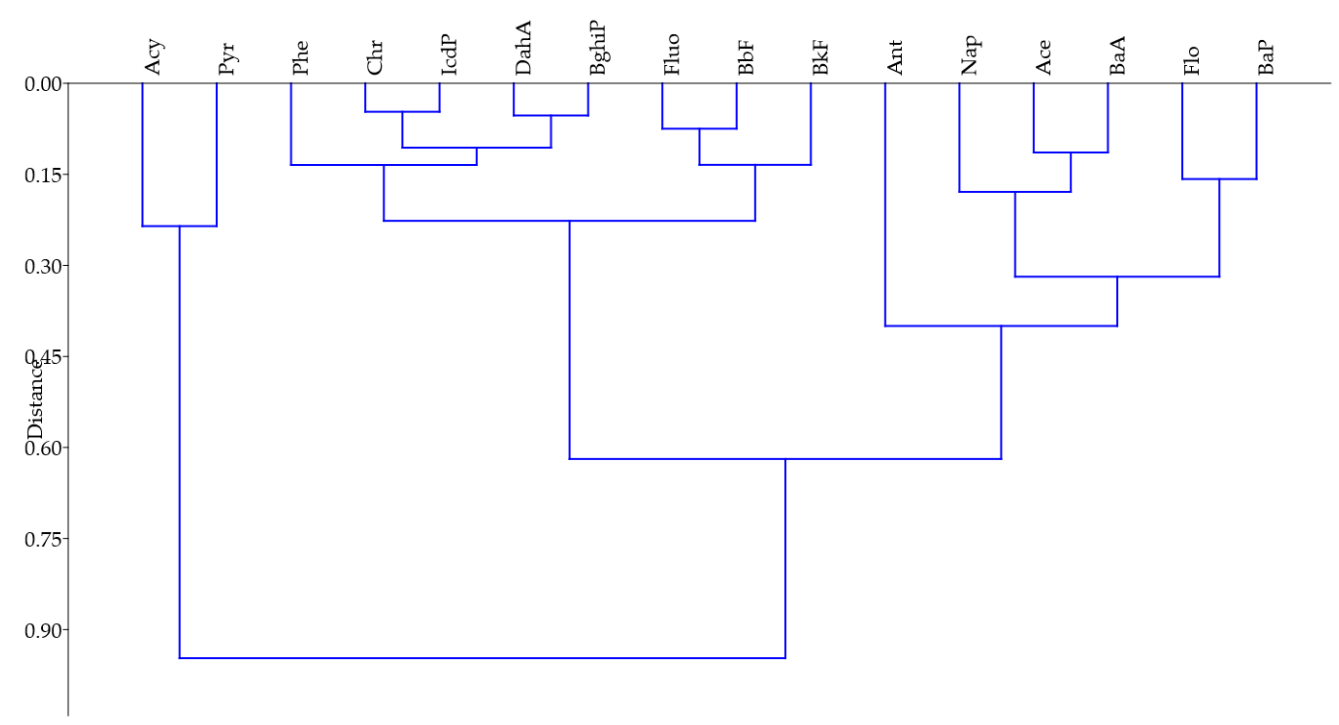

Figure 4. Path hierarchical clustering analysis per PAHs components.

The results of the CA yield a slightly similar result like PCA. From the results, three main groups can be identified. Acy and Pyr (Group 1) and Phe, Chr, IcdP, DahA, BghiP, Fluo, BbF and BkF (Group 2) and Ant, Nap, Ace, BaA, Flo and BaP (Group 3), indicating that the pollutants in the similar group might have similar sources (Figure 4), which was also confirmed by PCA.

\subsection{Source Identification of PAHs in Soils (PAHs Molecular Ratios)}

The PAHs sources can be summarized into groups by origin: pyrogenic, petrogenic, and phytogenic [4]. Diagnostic PAHs molecular ratio methods were used for the identification of PAHs sources of the contamination: Fluo/(Fluo+Pyr), low molecular weight (LMW) (2-3 rings)/high molecular weight (HMW) ( $\geq 4$ rings), IcdP/(IcdP+BghiP), BaA/(BaA+Chr), $\Sigma \mathrm{COMB} / \mathrm{TPAH}$ and PAH4/ PAH(5+6) [61-63,3-5], by comparing the concentrations of individual PAHs (Fluo, Pyr, BaA, Chr, IcdP, BghiP, Ant, Phe, BaP, etc.) and qualitatively distinguishing pyrolytic and petrogenic sources [63]. Molecular ratios can help to elucidate the origin of PAH in the environment [43].

In the study, four specific diagnostic molecular ratios of PAHs were used for the identification of sources of PAHs pollution: LMW/HMW, Fluo/(Fluo+Pyr), IcdP/(IcdP+BghiP) and BaA/(BaA+Chr) (Figure 5).

The LMW/HMW ratios between low and high molecular weight PAHs were interpreted by source apportionment [52]. Soils and groundwater have a higher mean value compared to those from urban areas, with a mean value of 0.70 (from 0 to 2.28). Values of $\geq 1$ indicate petrogenic source and of $\leq 1$ pyrogenic combustion $[64,43]$. These values indicate that the most likely sources of PAHs in location Incel in Banja Luka may be related to emissions from pyrogenic (combustion) origin and partially petrogenic source.

Fluo/(Fluo + Pyr) ratios with mean 0.01 ranged from 0 to 0.08. Yunker et al. (2002) [61] reported that the most likely sources of PAHs with value of $<0.20$ are from petroleum/petrogenic source. Values Fluo/(Fluo + Pyr) of 0.4-0.5 indicate fossil fuel combustion and of $>0.5$ biomass and coal combustion $[61,43,28]$.

$\mathrm{BaA} /(\mathrm{BaA}+\mathrm{Chr})$ values range from 0 to 1 (mean value of 0.62 ) and these values indicate ratio traffic emission and partially petrogenic source in three localities. Yunker et al. [61] explain that value (> 0.35) indicates traffic emission, Tobiszewski \& Namieśnik [65] values 0.2-0.35 indicate coal combustion and Davis et al. [56] $\mathrm{BaA} /(\mathrm{BaA}+\mathrm{Chr})$ values $<0.20$ indicate petrogenic source. Value below of 0.4 is characteristic of a petroleum source suggesting a combustion influence [52] (Figure 5).

Ratios of IcdP/(IcdP+BghiP) had mean value 0.54 (from 0 to 1 ) indicating that it is a source of pollution of PAHs coal and biomass combustion and partially fuel combustion in two localities 
(pyrogenic source). [65] reported that the coal and biomass combustion is $>0.50$ and fuel combustion ranges from 0.20 to 0.50 .

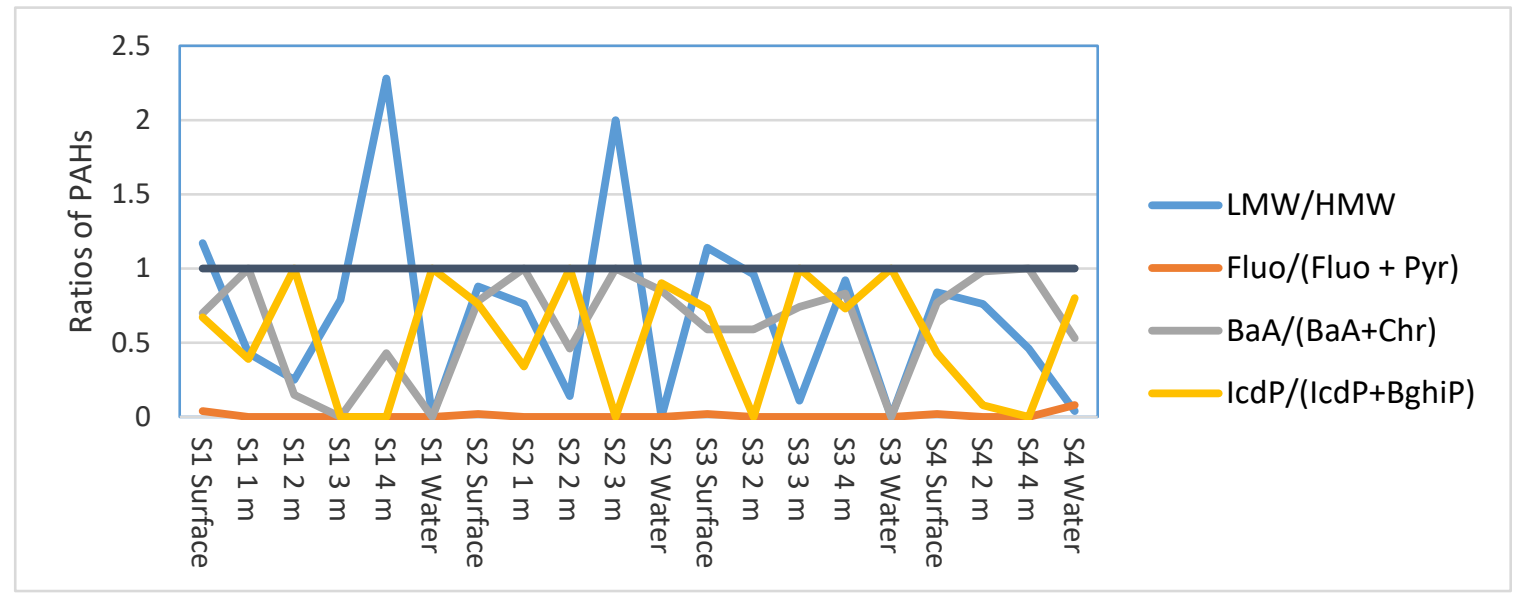

Figure 5. Specific diagnostic molecular ratios of PAHs.

The contribution of the LMW was of $69.41 \%$, while HMW was $30.59 \%$, which suggested petrogenic sources [66].

\subsection{Ecological Risk of PAHs in Soils and Groundwater}

PAHs in soils may enter water bodies, which poses a potential environmental risk [3]. The ecological risk of PAHs was assessed by a risk quotient method based on toxic equivalency factors [39]. A risk quotient (RQ) was used to assess the ecological risk of PAHs [40] and shown in Table 9. according to risk quotient $\left(\mathrm{RQ}_{(\mathrm{NCS})}\right.$ and $\left.\mathrm{RQ}_{(\mathrm{MPC})}\right)$ in research Kalf et al. [40], Wang et al. [3] and Lan et al. [41].

The result of $R Q_{(\mathrm{NCS})}$ and $R Q_{(\mathrm{MPC})}$ in soil and groundwater are shown in Table 9 . The mean values of $\mathrm{RQ}_{(\mathrm{NCs})}$ of $\mathrm{BbF}$ in the surface layer of soil are higher than 1.0 for $\sum 16 \mathrm{PAHs}$, except for IcdP and Chr and results indicate high ecological risk in location. Results for IcdP (0.34) and Chr (0.56) indicate moderate ecological risks. High ecological risks are at a depth of $100 \mathrm{~cm}$ for $\mathrm{BbF}$ (16.00), BaP (23.08), Ant (16.67), Acy (8.33), BaA (12.00), Phe (9.80), Flo (1.54), Nap (21.43), Ace (8.33) and Fluo (41.67), at a depth of $200 \mathrm{~cm} \mathrm{BbF}$ (8.00), BaP (11.54), Ant (16.67), Acy (33.33), Pyr (16.67), BaA (8.00), Phe (9.80), Nap (7.14), Ace (8.33) and Fluo (8.33). At a depth of $300 \mathrm{~cm}$ high ecological risk are for BbF, BaP, Ant, $\mathrm{BaA}$, Phe and Fluo, with values 8.00, 7.69, 8.33, 12.00, 5.88 and 16.67, respectively. At a depth of 400 $\mathrm{cm}$ high ecological risk are for BbF, BaP, Ant, DahA, Pyr, Phe, and Nap, with values 4.00, 11.54, 25.00, $8.33,5.88$ and 7.14 , respectively.

The mean values of ecological risk in soil and groundwater decreased with soil depth. Values of groundwater are a high ecological risk, for Ant, Chr, DahA, Acy, Pyr, BaA, Phe, Flo, Nap, Ace and Fluo, with values 28.57, 20.59, 300.00, 242.86, 185.71, 1700.0, 76.67, 53.33, 15.83, 100.00 and 57.14, respectively.

Low molecular PAHs (2, 3, 4-ring) are mutagenic and carcinogenic [3]. In Table 9 that groundwater risk is associated with low and molecular PAHs and indicates high ecological risk. 2, 3, 4ring PAHs mainly contributed to the ecological risk in groundwater, with the exception of DahA (5ring PAHs), while 5, 6-ring PAHs indicated the high ecological risks in soils. The RQ(NCs) of HMW PAHs in soils was higher than that in groundwater. 
14 of 19

Table 9. Descriptive statistics of $\mathrm{RQ}_{(\mathrm{NCs})}$ and $\mathrm{RQ}_{(\mathrm{MPC})}$ of $\mathrm{PAHs}(\mathrm{mg} / \mathrm{kg})$ in soils and groundwater.

\begin{tabular}{|c|c|c|c|c|c|c|c|c|c|c|c|c|c|c|c|c|}
\hline \multirow{4}{*}{$\begin{array}{c}\text { PAHs } \\
\mathrm{BbF}\end{array}$} & \multirow{3}{*}{\multicolumn{2}{|c|}{$\begin{array}{cc}\text { NCS } & \text { MCS } \\
\text { Soil }\end{array}$}} & \multirow{3}{*}{\multicolumn{2}{|c|}{$\begin{array}{c}\text { NCS MCS } \\
\text { Water }\end{array}$}} & \multicolumn{2}{|c|}{$30 \mathrm{~cm}$} & \multicolumn{2}{|c|}{$100 \mathrm{~cm}$} & \multicolumn{2}{|c|}{$200 \mathrm{~cm}$} & \multicolumn{2}{|c|}{$300 \mathrm{~cm}$} & \multicolumn{2}{|c|}{$400 \mathrm{~cm}$} & \multicolumn{2}{|c|}{ Groundwater } \\
\hline & & & & & \multicolumn{12}{|c|}{ 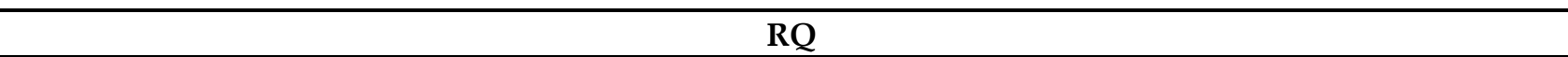 } \\
\hline & & & & & \multirow{2}{*}{$\begin{array}{r}\text { NCs } \\
56.00\end{array}$} & \multirow{2}{*}{$\begin{array}{l}\text { PCs } \\
0.56\end{array}$} & \multirow{2}{*}{$\begin{array}{r}\text { NCs } \\
16.00\end{array}$} & \multirow{2}{*}{$\begin{array}{l}\text { PCs } \\
0.16\end{array}$} & \multirow{2}{*}{$\begin{array}{l}\text { NCs } \\
8.00\end{array}$} & \multirow{2}{*}{$\begin{array}{l}\text { PCs } \\
0.08\end{array}$} & \multirow{2}{*}{$\begin{array}{l}\text { NCs } \\
8.00\end{array}$} & \multirow{2}{*}{$\begin{array}{l}\text { PCs } \\
0.08\end{array}$} & \multirow{2}{*}{$\begin{array}{l}\text { NCs } \\
4.00\end{array}$} & \multirow{2}{*}{$\begin{array}{c}\text { PCs } \\
0.04\end{array}$} & \multirow{2}{*}{$\begin{array}{l}\text { NCs } \\
0.00\end{array}$} & \multirow{2}{*}{$\begin{array}{c}\text { PCs } \\
0.00\end{array}$} \\
\hline & 0.0025 & 0.25 & 0.0001 & 0.01 & & & & & & & & & & & & \\
\hline $\mathrm{BkF}$ & 0.024 & 2.4 & 0.0004 & 0.04 & 10.00 & 0.10 & 0.42 & 0.00 & 0.42 & 0.00 & 0.42 & 0.00 & 0.42 & 0.00 & 0.00 & 0.00 \\
\hline $\mathrm{BaP}$ & 0.0026 & 0.26 & 0.0005 & 0.05 & 34.62 & 0.00 & 23.08 & 0.23 & 11.54 & 0.12 & 7.69 & 0.08 & 11.54 & 0.12 & 0.00 & 0.00 \\
\hline BghiP & 0.075 & 7.5 & 0.0003 & 0.03 & 2.00 & 0.02 & 0.13 & 0.00 & 0.13 & 0.00 & 0.00 & 0.00 & 0.40 & 0.00 & 0.00 & 0.67 \\
\hline IcdP & 0.059 & 5.9 & 0.0004 & 0.04 & 0.34 & 0.00 & 0.17 & 0.00 & 0.17 & 0.00 & 0.17 & 0.00 & 0.68 & 0.01 & 0.00 & 0.00 \\
\hline Ant & 0.0012 & 0.12 & 0.0007 & 0.07 & 166.67 & 1.67 & 16.67 & 0.17 & 16.67 & 0.17 & 8.33 & 0.08 & 25.00 & 0.25 & 28.57 & 0.29 \\
\hline Chr & 0.107 & 10.7 & 0.0034 & 0.34 & 0.56 & 0.01 & 0.28 & 0.00 & 0.19 & 0.00 & 0.19 & 0.00 & 0.28 & 0.00 & 20.59 & 0.21 \\
\hline DahA & 0.0026 & 0.26 & 0.0005 & 0.05 & 146.15 & 1.46 & 0.00 & 0.00 & 0.00 & 0.00 & 0.00 & 0.00 & 3.85 & 0.04 & 300.00 & 3.00 \\
\hline Acy & 0.0012 & 0.12 & 0.0007 & 0.07 & 91.67 & 0.92 & 8.33 & 0.08 & 33.33 & 0.33 & 0.00 & 0.00 & 0.00 & 0.00 & 242.86 & 2.43 \\
\hline Pyr & 0.0012 & 0.12 & 0.0007 & 0.07 & 25.00 & 0.25 & 0.00 & 0.00 & 16.67 & 0.17 & 0.00 & 0.00 & 8.33 & 0.08 & 185.71 & 1.86 \\
\hline $\mathrm{BaA}$ & 0.0025 & 0.25 & 0.0001 & 0.01 & 24.00 & 0.24 & 12.00 & 0.12 & 8.00 & 0.08 & 12.00 & 0.12 & 0.00 & 0.00 & 1700.0 & 17.00 \\
\hline Phe & 0.0051 & 0.51 & 0.003 & 0.3 & 7.84 & 0.08 & 9.80 & 0.10 & 9.80 & 0.10 & 5.88 & 0.06 & 5.88 & 0.06 & 76.67 & 0.77 \\
\hline Flo & 0.026 & 2.6 & 0.003 & 0.3 & 4.23 & 0.04 & 1.54 & 0.02 & 0.77 & 0.01 & 0.77 & 0.01 & 0.38 & 0.00 & 53.33 & 0.53 \\
\hline Nap & 0.0014 & 0.14 & 0.012 & 1.2 & 21.43 & 0.21 & 21.43 & 0.21 & 7.14 & 0.07 & 0.00 & 0.00 & 7.14 & 0.07 & 15.83 & 0.16 \\
\hline Ace & 0.0012 & 0.12 & 0.0007 & 0.07 & 16.67 & 0.17 & 8.33 & 0.08 & 8.33 & 0.08 & 0.00 & 0.00 & 0.00 & 0.00 & 100.00 & 1.00 \\
\hline Fluo & 0.0012 & 0.12 & 0.0007 & 0.07 & 16.67 & 0.17 & 41.67 & 0.42 & 8.33 & 0.08 & 16.67 & 0.17 & 0.00 & 0.00 & 57.14 & 0.57 \\
\hline $\begin{array}{c}\sum 16 \\
\text { PAHs }\end{array}$ & & & & & 623.84 & 5.89 & 159.85 & 1.60 & 129.49 & 1.29 & 60.12 & 0.60 & 67.90 & 0.68 & 2780.7 & 28.47 \\
\hline
\end{tabular}


The value of $R_{(N C s)}$ for $\Sigma P A H s$ was less than 800 , while values of $R Q_{(M P C s)}$ were higher than 1 , indicating that the $\mathrm{PPAHs}$ in the surface layer of soils were assigned a moderate ecological risk 2 level. Moderate risk 2 level is also at depths of $100 \mathrm{~cm}$ and $200 \mathrm{~cm}$ (Table 8). At depths of $300 \mathrm{~cm}$ and $400 \mathrm{~cm}$ values indicate low ecological risk. The value of $R_{(\mathrm{NCs})}$ for $\Sigma \mathrm{PAHs}$ in groundwater indicates high ecological risk ( $\Sigma \mathrm{PAHs} \geq 800$ and $\mathrm{RQ}_{(\mathrm{MPC} s)} \geq 1$ ).

The monitoring of PAHs in groundwater and soil in an industrial complex should be given greater attention. In this industrial complex, the construction of residential and commercial buildings is planned. On the other hand, the alluvial character of the land and the proximity of the Vrbas River require more attention because arable land, as well as agricultural irrigation, are located near and downstream. It is still common for households to have their own wells where they use water for drinking, feeding livestock and irrigation. Accordingly, continuous monitoring at a number of locations in the industrial complex is necessary to determine the spatial and temporal distribution of PAHs. The analysis of PAHs must be done in soil, groundwater, but also in air and sediment in the Vrbas River, because of the close proximity to the Vrbas River. It is imperative to adopt regulations governing permissible limits in industrial soils and to initiate urgent remediation in the location. Measures should be implemented to quickly reduce and eliminate the pollution of PAHs in the location.

\section{Conclusions}

In this research, the $\sum 16 \mathrm{PAHs}$ in the soil (at a depth of up to $30 \mathrm{~cm}, 100 \mathrm{~cm}, 200 \mathrm{~cm}, 300 \mathrm{~cm}$ and $400 \mathrm{~cm}$ ) ranged from 0.99 to $2.24 \mathrm{mg} / \mathrm{kg}$, from 0.34 to 0.46 , from 0.24 to 0.32 , from 0.13 to 0.27 and from 0.13 to 0.47 , with mean values of $1.70 \mathrm{mg} / \mathrm{kg}, 0.40 \mathrm{mg} / \mathrm{kg}, 0.28 \mathrm{mg} / \mathrm{kg}, 0.20 \mathrm{mg} / \mathrm{kg}$ and $0.26 \mathrm{mg} / \mathrm{kg}$, respectively. The $\sum 16 \mathrm{PAHs}$ in groundwater ranged from 0.23 to $4.50 \mathrm{mg} / \mathrm{m}^{3}$, with a mean value of $1.42 \mathrm{mg} / \mathrm{m}^{3}$. According to the national standards, the concentrations of $\sum 16 \mathrm{PAHs}$ found in this study are higher in one location and lower in other locations than the permissible value of $2 \mathrm{mg} / \mathrm{kg}$ in agricultural soils. Soil and groundwater are heavily contaminated (heavily polluted) in the surface layer of soil $(0-30 \mathrm{~cm})$. The study indicated that PAHs concentration in the industrial complex and in different layers of soil and groundwater were high. The significantly higher values of $\Sigma 16 \mathrm{PAHs}$ in the surface soil layer compared to other soil layers indicate that there is a fresh intake of PAHs at the site, with pre-existing historical pollution. The measured value indicates that groundwater is highly polluted and that groundwater is classified in the fifth class of water quality, and those are heavily polluted waters that can be used for almost no purpose. The flow of groundwater has a significant influence in PAH concentrations since a significantly higher concentration of PAHs is observed in groundwater compared to the soil at research sites. The $\Sigma 16 \mathrm{PAH}$ is the highest in surface layer of soil, and with increasing the depth it decreases.

Maximum $\sum 16 \mathrm{PAHs}$ values were observed at $0-30 \mathrm{~cm}$ and PAH concentrations decreased with depth in the different soil layers, and PAHs were dominantly accumulated in the surface soil layer.

The relationship between the components of PAHs levels in soils and groundwater and anthropogenic activities was examined, using factor analysis (FA). Three components accounted for $86.99 \%$ of the total variance. The source analysis of soil PAHs demonstrated that the main causes of PAHs are coal combustion (pyrogenic) (PC1 factor included BaA, BaP, BbF, BghiP, BkF, Chr, DahA, Fluo, and IcdP), petroleum sources (petrogenic) (PC2 factor included Acy, Ant, Nap and Pyr) and biomass combustion (PC3 factor included Ace, Flo, and Phe). The results of the hierarchical cluster analysis (CA) yield a slightly similar result like principal components analysis. From the results, three main groups can be identified. Acy and Pyr (Group 1) and Phe, Chr, IcdP, DahA, BghiP, Fluo, BbF, and BkF (Group 2) and Ant, Nap, Ace, BaA, Flo, and BaP (Group 3).

In the study, four specific diagnostic molecular ratios of PAHs were used for the identification of sources of PAHs pollution. The LMW/HMW ratios indicate that the most likely sources of PAHs related to emissions from pyrogenic (combustion) origin and partially petrogenic source. Fluo/(Fluo+Pyr) ratios indicate that the most likely sources of PAHs are petroleum/petrogenic sources. $\mathrm{BaA} /(\mathrm{BaA}+\mathrm{Chr})$ ratios indicate traffic emission and partially petrogenic sources. IcdP/(IcdP+BghiP) 
ratios indicate that the sources of PAHs pollution are coal and biomass combustion and partially fuel combustion (pyrogenic source).

The ecological risk assessment in layers of soil and groundwater indicates that there is a high ecological risk of PAHs in the location. The mean values of ecological risk in soil and groundwater decreased with soil depth and groundwater.

The results of this study reflect the effects of the coal combustion (pyrogenic origin), petrogenic and biomass origin and may provide basic data for the PAHs remediation in location. This is the first study on levels of PAHs in soil and groundwater in industrial soils in Banja Luka and provides baseline information for further studies and additional examination about this industrial complex. There is a need to determine the health risk level in this area and the ecotoxicity of PAHs.

Author Contributions: Conceptualization, P.I., D.NM. and LJ.SB.; methodology, P.I. and D.NM.; software, P.I. and D.NM.; writing - original draft preparation, P.I., D.NM. and LJ.SB.; writing and editing, P.I., D.NM. and LJ.SB. The three authors contributed equally to this work and have read and agreed to the published version of the manuscript.

Funding: This research was funded by Ministry for Scientific and Technological Development, Higher Education and Information Society of Republic of Srpska, grant number 19/6-020/961-96/18.

Acknowledgments: The present study was conducted using equipment from the PSRI Institute for Protection and Ecology of the Republic of Srpska, Banja Luka.

Conflicts of Interest: The authors declare no conflict of interest.

\section{References}

1. Guo, J.; Chai, C.; Ge, W.; Zeng, L.; Wu, J.; Xiang, D.; Zhang, X. Accumulation and Health Risk Assessment of PAHs in Radish. Pol. J. Environ. Stud. 2018, 27, 2529-2539.

2. Ding, Y.; Huang; H.; Zhang, Y.; Zheng, H.; Zeng, F.; Chen, W.; Qu, C.; Li, X.; Xing, X.; Qi, S. Polycyclic aromatic hydrocarbons in agricultural soils from Northwest Fujian, Southeast China: Spatial distribution, source apportionment, and toxicity evaluation. J. Geochem. Explor. 2018, 195, 121-129.

3. Wang, D.; Ma, J.; Li, H.; Zhang, X. Concentration and potential ecological risk of PAHs in different layers of soil in the petroleum-contaminated areas of the Loess Plateau, China. Int. J. Environ. Res. Public Health. 2018, 15, 1785.

4. Alsbou, E.; Zaitoun, M.A.; Alasoufi, A.M.; Al Shra'ah, A. Concentration and Source Assessment of Polycyclic Aromatic Hydrocarbons in the Street Soil of Ma'an City, Jordan. Arch. Environ. Contam. Toxicol. 2019, 77, 619-630.

5. Thiombane, M.; Albanese, S.; Di Bonito, M.; Lima, A.; Zuzolo, D.; Rolandi, R.; Qi, S.; De Vivo, B. Source patterns and contamination level of polycyclic aromatic hydrocarbons (PAHs) in urban and rural areas of Southern Italian soils. Environ. Geochem. Health. 2019, 41, 507-528.

6. Zeng, S.; Ma, J.; Ren, Y.; Liu, G.J.; Zhang, Q.; Chen, F. Assessing the Spatial Distribution of Soil PAHs and their Relationship with Anthropogenic Activities at a National Scale. Int. J. Environ. Res. Public Health. 2019, $16,4928$.

7. Abdel-Shafy, H.I.; Mansour, M.S. A review on polycyclic aromatic hydrocarbons: source, environmental impact, effect on human health and remediation. Egypt. J. Pet. 2016, 25, 107-123.

8. Nadal, M.; Schuhmacher, M.; Domingo, J.L. Levels of PAHs in soil and vegetation samples from Tarragona County, Spain. Environ. Pollut. 2004, 132, 1-11.

9. Lamichhane, S.; Krishna, K.B.; Sarukkalige, R. Polycyclic aromatic hydrocarbons (PAHs) removal by sorption: a review. Chemosphere. 2016, 148, 336-353.

10. Kim, K.H.; Jahan, S.A.; Kabir, E.; Brown, R.J. A review of airborne polycyclic aromatic hydrocarbons (PAHs) and their human health effects. Environ. Int. 2013, 60, 71-80.

11. Hussain, K.; Hoque, R.R.; Balachandran, S.; Medhi, S.; Idris, M.G.; Rahman, M.; Hussain, F.L. Monitoring and risk analysis of PAHs in the environment. In: Handbook of Environmental Materials Management, Hussain, C., Eds.; Publisher: Springer, Cham, 2018; pp. 1-35.

12. Skupinska, K.; Misiewicz, I.; Kasprzycka-Guttman, T. Polycyclic aromatic hydrocarbons: physicochemical properties, environmental appearance and impact on living organisms. Acta Pol. Pharm. 2004, 61, 233-240. 
13. Li, J.; Li, F.; Liu, Q. PAHs behavior in surface water and groundwater of the Yellow River estuary: evidence from isotopes and hydrochemistry. Chemosphere. 2017, 178, 143-153.

14. Rodríguez-Escales, P.; Borràs, E.; Sarra, M.; Folch, A. Granulometry and surfactants, key factors in desorption and biodegradation (T. Versicolor) of PAHs in soil and groundwater. Water Air Soil Pollut. 2013, $224,1422$.

15. Tang, L.; Tang, X.Y.; Zhu, Y.G.; Zheng, M.H.; Miao, Q.L. Contamination of polycyclic aromatic hydrocarbons (PAHs) in urban soils in Beijing, China. Environ. Int. 2005, 31, 822-828.

16. Nizzetto, L.; Lohmann, R.; Gioia, R.; Jahnke, A.; Temme, C.; Dachs, J.; Herckes, P.; Di Guardo, A.; Jones, K.C. PAHs in air and seawater along a North-South Atlantic transect: trends, processes and possible sources. Environ. Sci. Technol. 2008, 42, 1580-1585.

17. Srogi, K. Monitoring of environmental exposure to polycyclic aromatic hydrocarbons: a review. Environ. Chem. Lett. 2007, 5, 169-195.

18. De Nicola, F.; Alfani, A.; Maisto, G. Polycyclic aromatic hydrocarbon contamination in an urban area assessed by Quercus ilex leaves and soil. Environ. Sci. Pollut. Res. Int. 2014, 21, 7616-7623.

19. Lee, B.K. Sources, distribution and toxicity of polyaromatic hydrocarbons (PAHs) in particulate matter. In In: Air pollution. Kumar, A., Eds.; Publisher: IntechOpen, 2010.

20. Aichner, B.; Bussian, B.M.; Lehnik-Habrink, P.; Hein, S. Regionalized concentrations and fingerprints of polycyclic aromatic hydrocarbons (PAHs) in German forest soils. Environ. Pollut. 2015, 203, 31-39.

21. Motelay-Massei, A.; Ollivon, D.; Garban, B.; Teil, M.J.; Blanchard, M.; Chevreuil, M. Distribution and spatial trends of PAHs and PCBs in soils in the Seine River basin, France. Chemosphere. 2004, 55, 555-565.

22. Weiss, P.; Riss, A.; Gschmeidler, E.; Schentz, H. Investigation of heavy metal, PAH, PCB patterns and PCDD/F profiles of soil samples from an industrialized urban area (Linz, Upper Austria) with multivariate statistical methods. Chemosphere, 1994, 29, 2223-2236.

23. Zuo, Q.; Duan, Y.H.; Yang, Y.; Wang, X.J.; Tao, S. Source apportionment of polycyclic aromatic hydrocarbons in surface soil in Tianjin, China. Environ. Pollut. 2007, 147, 303-310.

24. Mielke, H.W.; Wang, G.; Gonzales, C.R.; Powell, E.T.; Le, B.; Quach, V.N. PAHs and metals in the soils of inner-city and suburban New Orleans, Louisiana, USA. Environ. Toxicol. Pharmacol. 2004, 18, 243-247.

25. Nieuwoudt, C.; Pieters, R.; Quinn, L.P.; Kylin, H.; Borgen, A.R.; Bouwman, H. Polycyclic aromatic hydrocarbons (PAHs) in soil and sediment from industrial, residential, and agricultural areas in central South Africa: An initial assessment. Soil Sediment Contam. 2011, 20, 188-204.

26. Aislabie, J.; Balks, M.; Astori, N.; Stevenson, G.; Symons, R. Polycyclic aromatic hydrocarbons in fuel-oil contaminated soils, Antarctica. Chemosphere. 1999, 39, 2201-2207.

27. Brindha, K.; Elango, L. (2014). PAHs contamination in groundwater from a part of metropolitan city, India: a study based on sampling over a 10-year period. Environ. Earth Sci. 2014, 71, 5113-5120.

28. Sun, Y.; Zhang, S.; Lan, J.; Xie, Z.; Pu, J.; Yuan, D.; Yang, H.; Xing, B. Vertical migration from surface soils to groundwater and source appointment of polycyclic aromatic hydrocarbons in epikarst spring systems, southwest China. Chemosphere. 2019, 230, 616-627.

29. Sapcanin, A.; Cakal, M.; Jacimovic, Z.; Pehlic, E.; Jancan, G. Soil pollution fingerprints of children playgrounds in Sarajevo city, Bosnia and Herzegovina. Environ. Sci. Pollut. Res. Int. 2017, 24, 10949-10954.

30. Pribylova, P.; Kares, R.; Boruvkova, J.; Cupr, P.; Prokes, R.; Kohoutek, J.; Holoubek, I.; Klanova, J. Levels of persistent organic pollutants and polycyclic aromatic hydrocarbons in ambient air of Central and Eastern Europe. Atmos. Pollut. Res. 2012, 3, 494-505.

31. Djedjibegovic, J.; Marjanovic, A.; Sober, M.; Skrbo, A.; Sinanovic, K.; Larssen, T.R.; Grund. M.; Fjeld, E.; Rognerud, S. Levels of persistent organic pollutants in the Neretva River (Bosnia and Herzegovina) determined by deployment of semipermeable membrane devices (SPMD). J. Environ. Sci. Health B. 2010, 45, 128-136.

32. Lammel, G.; Klánová, J.; Ilić, P.; Kohoutek, J.; Gasić, B.; Kovacić, I.; Lakić, N.; Radić, R. Polycyclic aromatic hydrocarbons in air on small spatial and temporal scales-I. Levels and variabilities. Atmos. Environ. 2010, 44, 5015-5021.

33. Lammel, G.; Klánová, J.; Ilić, P.; Kohoutek, J.; Gasić, B.; Kovacić, I.; Škrdlíková, L. Polycyclic aromatic hydrocarbons in air on small spatial and temporal scales-II. Mass size distributions and gas-particle partitioning. Atmos. Environ. 2010, 44, 5022-5027.

34. Cao, W.; Yin, L.; Zhang, D.; Wang, Y.; Yuan, J.; Zhu, Y.; Dou, J. (2019). Contamination, Sources, and Health Risks Associated with Soil PAHs in Rebuilt Land from a Coking Plant, Beijing, China. Int. J. Environ. Res. Public Health. 2019, 16, 670. 
35. Ilić, P.; Nišić, T.; Ilić, S.; Stojanović Bjelić, LJ. The identification of new 'hotspot' of heavy metal contamination of soil in industrial zone. Pol. J. Environ. Stud. (accepted on 15/10/2019, online DOI: https://doi.org/10.15244/pjoes/113095).

36. Kononova, M.M. Soil Organic Matter, 2nd ed.; Publisher: Pergamon Press, Oxford. 1966; p. 378.

37. Rulebook on allowable quantities of dangerous and hazardous matters in soil and irrigation water and methods for their testing ("Official Gazette of the Republic of Srpska", No. 56/16).

38. Regulation on the classification of waters and categorization of watercourses ("Official Gazette of the Republic of Srpska", No. 42/01).

39. US-EPA, Method 8270D, 2007. Semivolatile Organic Compounds by Gas Chromatography Mass Spectrometry. US Environmental Protection Agency.

40. Kalf, D.F.; Crommentuijn, T.; van de Plassche, E.J. Environmental quality objectives for 10 polycyclic aromatic hydrocarbons (PAHs). Ecotoxicol. Environ. Saf. 1997, 36, 89-97.

41. Lan, J.; Sun, Y.; Xiang, X. Ecological Risk Assessment of PAHs in a Karst Underground River System. Pol. J. Environ. Stud. 2020, 29, 677-687.

42. Konstantinova, E.; Minkina, T.; Sushkova, S.; Antonenko, E.; Konstantinov, A. (). Levels, sources, and toxicity assessment of polycyclic aromatic hydrocarbons in urban topsoils of an intensively developing Western Siberian city. Environ. Geochem. Health. 2019, 1-17.

43. Zhang, J.; Yang, J.C.; Wang, R.Q.; Hou, H.; Du, X.M.; Fan, S.K.; Liu, J.S.; Dai, J.L. Effects of pollution sources and soil properties on distribution of polycyclic aromatic hydrocarbons and risk assessment. Sci. Total Environ. 2013, 463, 1-10.

44. Jiao, H.; Wang, Q.; Zhao, N.; Jin, B.; Zhuang, X.; Bai, Z.. Distributions and sources of polycyclic aromatic hydrocarbons (PAHs) in soils around a chemical plant in Shanxi, China. Int. J. Environ. Res. Public Health. 2017, 14, 1198

45. Kim, A.W.; Vane, C.H.; Moss-Hayes, V.L.; Beriro, D.J.; Nathanail, C.P.; Fordyce, F.M.; Everett, P.A. Polycyclic aromatic hydrocarbons (PAHs) and polychlorinated biphenyls (PCBs) in urban soils of Glasgow, UK. Earth Environ. Sci. Trans. R. Soc. Edinb. 2018, 108, 231-247.

46. Morillo, E.; Romero, A.S.; Maqueda, C.; Madrid, L.; Ajmone-Marsan, F.; Grcman, H.; Davidson, C.M.; Villaverde, J. Soil pollution by PAHs in urban soils: a comparison of three European cities. J. Environ. Monit. 2007, 9, 1001-1008.

47. Bogan, B.W.; Sullivan, W.R. Physicochemical soil parameters affecting sequestration and mycobacterial biodegradation of polycyclic aromatic hydrocarbons in soil. Chemosphere, 2003, 52, 1717-172

48. Tsibart, A.S., Gennadiev, A.N. Polycyclic aromatic hydrocarbons in soils: sources, behavior, and indication significance (a review). Eurasian Soil Sci. 2013, 46, 728-741.

49. Conte, P.; Zena, A.; Pilidis, G.; Piccolo, A. Increased retention of polycyclic aromatic hydrocarbons in soils induced by soil treatment with humic substances. Environ. Pollut. 2001, 112, 27-31.

50. Nam, J.J.; Thomas, G.O.; Jaward, F.M.; Steinnes, E.; Gustafsson, O.; Jones, K.C. PAHs in background soils from Western Europe: influence of atmospheric deposition and soil organic matter. Chemosphere. 2008, 70, 1596-1602.

51. Radu, V.M.; Ionescu, P.; Deak, G.; Diacu, E.; Ivanov, A.A.; Zamfir, S.; Marcus, M.I. Overall assessment of surface water quality in the Lower Danube River. Environ. Monit. Assess. 2020, 192, 135.

52. Parra, Y. J.; Oloyede, O.O.; Pereira, G.M.; de Almeida Lima, P.H.A.; da Silva Caumo, S.E.; Morenikeji, O.A.; de Castro Vasconcellos, P. Polycyclic aromatic hydrocarbons in soils and sediments in Southwest Nigeria. Environ. Pollut. 2020, 259, 113732.

53. Liu, C.W.; Lin, K.H.; Kuo, Y.M. Application of factor analysis in the assessment of groundwater quality in a blackfoot disease area in Taiwan. Sci. Total Environ. 2003, 313, 77-89.

54. Harrison, R.M.; Smith, D.J.T.; Luhana, L. Source apportionment of atmospheric polycyclic aromatic hydrocarbons collected from an urban location in Birmingham, UK. Environ. Sci. Technol. 1996, 30, 825-832.

55. Iwegbue, C.M.; Obi, G.; Aganbi, E.; Ogala, J.E.; Omo-Irabor, O.O.; Martincigh, B.S. Concentrations and health risk assessment of polycyclic aromatic hydrocarbons in soils of an urban environment in the Niger Delta, Nigeria. J. Toxicol. Environ. Health Sci. 2016, 8, 221-233.

56. Davis, E.; Walker, T.R.; Adams, M.; Willis, R.; Norris, G.A.; Henry, R.C. Source apportionment of polycyclic aromatic hydrocarbons (PAHs) in small craft harbor ( $\mathrm{SCH}$ ) surficial sediments in Nova Scotia, Canada. Sci. Total Environ. 2019, 691, 528-537. 
57. Tepanosyan, G.; Sahakyan, L.; Belyaeva, O.; Maghakyan, N.; Saghatelyan, A. Human health risk assessment and riskiest heavy metal origin identification in urban soils of Yerevan, Armenia. Chemosphere. 2017, 184, 1230-1240.

58. Bao, H.; Hou, S.; Niu, H.; Tian, K.; Liu, X.; Wu, F. Status, sources, and risk assessment of polycyclic aromatic hydrocarbons in urban soils of Xi'an, China. Environ. Sci. Pollut. Res. Int. 2018, 25, 18947-18959.

59. Uncumusaoğlu, A.A.; Mutlu, E. Evaluating spatial andtemporal variation in Tuzaklıpond water using multivariatestatistical analysis. Pol. J. Environ. Stud. 2019, 28, 1-14.

60. Dołęgowska, S.; Michalik, A. The use of a geostatistical model supported by multivariate analysis to assess the spatial distribution of mercury in soils from historical mining areas: Karczówka Mt., Miedzianka Mt., and Rudki (south-central Poland). Environ. Monit. Assess. 2019, 191, 302.

61. Yunker, M.B.; Macdonald, R.W.; Vingarzan, R.; Mitchell, R.H.; Goyette, D.; Sylvestre, S. PAHs in the Fraser River basin: a critical appraisal of $\mathrm{PAH}$ ratios as indicators of $\mathrm{PAH}$ source and composition. Org. Geochem. 2002, 33, 489-515.

62. Iwegbue, C.M.; Tesi, G.O.; Obi, G.; Obi-Iyeke, G.E.; Igbuku, U.A.; Martincigh, B.S. Concentrations, health risks and sources of polycyclic aromatic hydrocarbons in Nigerian honey. J. Toxicol. Environ. Health Sci. 2016, 8, 28-42.

63. Han, J.; Liang, Y.; Zhao, B.; Wang, Y.; Xing, F.; Qin, L. Polycyclic aromatic hydrocarbon (PAHs) geographical distribution in China and their source, risk assessment analysis. Environ. Pollut. 2019, 251, 312-327.

64. Budzinski, H.; Jones, I.; Bellocq, J.; Pierard, C.; Garrigues, P.H. Evaluation of sediment contamination by polycyclic aromatic hydrocarbons in the Gironde estuary. Mar. Chem. 1997, 58, 85-97.

65. Tobiszewski, M.; Namieśnik, J. PAH diagnostic ratios for the identification of pollution emission sources. Environ. Pollut. 2012, 162, 110-119.

66. Keshavarzifard, M.; Zakaria, M.P.; Hwai, T.S. Bioavailability of polycyclic aromatic hydrocarbons (PAHs) to short-neck clam (Paphia undulata) from sediment matrices in mudflat ecosystem of the west coast of Peninsular Malaysia. Environ. Geochem. Health. 2017, 39, 591-610. 